\title{
Rola Wisły jako rzeki gra nicznej na tle historycznych podziałów kraju i jej znaczenie w aktualnym podziale administracyjnym
}

Celem pracy jest zbadanie znaczenia Wisły jak rzeki granicznej zarówno w kontekście historycznych podziałów kraju, jak i w obowiązującym podziale administracyjnym. Na podstawie map i literatury możliwe było określenie, na jakich odcinkach i w jakich okresach Wisła stanowiła granicę zapożyczoną z natury i gdzie rola Wisły jako rzeki granicznej cechuje się największą stabilnością.

Słowa kluczowe: granice na rzekach, Wisła, podziały administracyjne.

\section{Wprowadzenie}

Proces kształtowania się granic Polski zarówno politycznych, jak i administracyjnych był długi i skomplikowany. Wpływało na niego wiele czynników, wśród których najważniejszą rolę odgrywało środowisko naturalne obszaru, na którym formował się pierwotny organizm państwowy. Naturalne bariery, takie jak duże rzeki czy łańcuchy górskie stanowiły trudno przekraczalne granice, zapewniające możliwość rozwoju poszczególnych jednostek prapaństwowych. To czy taki tworzący się organizm państwowy rozszerzy swoje terytorium do wspomnianych granic naturalnych, a tym bardziej czy będzie w stanie je przekroczyć, zależało głównie od jego potencjału demograficznego, ekonomicznego i militarnego, a także stopnia samoorganizacji. Proces ekspansji był uzależniony ponadto od wielu czynników zewnętrznych, wśród których wymienić należy: politykę sąsiadujących organizmów politycznych, szczególnie w odniesieniu do polityki zagranicznej, wspomniane wyżej trzy potencjały, a także potrzeby ekonomiczne, w rozumieniu zapotrzebowania na określone towary. Znaczenie miał także charakter sąsiadujących pranarodów - mogły być to przecież plemiona osiadłe lub koczownicze, nastawione pokojowo lub walecznie (Koter, Kulesza 2001).

Czynnik hydrograficzny odgrywał znaczącą rolę w rozmieszczeniu pierwotnego osadnictwa, które rozprzestrzeniało się wzdłuż głównych rzek, by z czasem rozciągnąc się na kolejne dopływy i w końcu objąć obszar całego dorzecza 
(Piskozub 1987). Teoria ta jest jak najbardziej uzasadniona dla obszaru Polski, gdzie podziały hydrograficzne, dorzeczy Wisły i Odry, łączyć można z głównymi obszarami plemiennymi. Dorzecze Wisły było podzielone pomiędzy trzy wielkie plemiona, zajmujące poszczególne dzielnice historyczne: w dorzeczu górnej Wisły (Małopolsce) zamieszkiwali Wiślanie, dorzecze środkowej Wisły (Mazowsze) było obszarem plemiennym Mazowszan, natomiast dorzecze dolnej Wisły (Pomorze Wschodnie) należało do Kaszubów (Koter, Kulesza 2001). W opisywanym okresie funkcję granic pełniły wododziały. Dopiero w kolejnych stuleciach rolę tę przenoszono na rzeki (Piskozub 1987).

Granice polityczne na rzekach określane są mianem „granic dyplomatów”, gdyż najłatwiej wyznaczyć je na mapach. Równocześnie są one najbardziej sztucznymi granicami spośród tzw. granic naturalnych, czyli takich, które oparte są na elementach hydrograficznych i geomorfologicznych. Wynika to z faktu, że w procesie historycznym rzeki były osiami osadnictwa i rozwoju poszczególnych regionów geograficzno-historycznych, których granice tworzyły się w strefach wododziałowych (Koter, Kulesza 2001). Należy jednak zauważyć, że delimitacja granicy wzdłuż biegu rzeki jest jedynie z pozoru łatwa. Cechą charakterystyczną wód płynących jest działalność erozyjna i akumulacyjna, co oznacza, że w pewnych szczególnych sytuacjach (np. wielkie powodzie) terytorium państwa, którego granicę stanowi rzeka, może ulegać odpowiednio pomniejszeniu lub powiększeniu, kosztem terytorium państwa sąsiedniego. Przyjęło się, że dla rzek uregulowanych granicę prowadzi się wzdłuż głównego nurtu, a w przypadku rzek nieuregulowanych - środkiem rzeki. Takie założenia delimitacyjne odnoszą się do granic politycznych (państwowych). Przy wyznaczaniu wewnętrznych granic administracyjnych, biegnących wzdłuż rzek, przesłankę tę traktowano raczej jako pewną sugestię. Świadczy o tym przebieg części aktualnych granic administracyjnych na Wiśle. Analizując te szczególne przypadki, nie sposób określić, jaką zasadą kierowano się przy ich delimitacji. Linia graniczna biegnie zarówno wzdłuż środka rzeki (granica na rzekach nieuregulowanych), środka nurtu (granica na rzekach uregulowanych), jak i wzdłuż linii brzegu, a także po samym brzegu (ryc. 1). Można przypuszczać, że przebieg ten ukształtowany został wcześniejszymi podziałami, na które nałożyły się zmiany koryta rzeki.

Badając przebieg historycznych podziałów administracyjnych Polski, w których Wisła stanowiła rzekę graniczną, należy pamiętać o ewolucyjnym znaczeniu terminu „granica”. Tak jak to było już wcześniej opisane, początkowo granice miały charakter strefowy. Granice linearne pojawiły się dużo później na osi czasu procesu historycznego. Jak pisze A. Piskozub (1987), dopiero w XIII w. granice międzydzielnicowe zaczęły przyjmować charakter linearny. Rozróżnienie tych dwóch typów granic ma zasadnicze znaczenie. Odnosząc się do prac historyka Tadeusza Manteuffla, na mapach ziem polskich $\mathrm{z}$ okresu od X do 
XIII w. granice strefowe przedstawiano błędnie jako granice linearne, zakłócając tym samym określenie pierwotnych układów terytorialnych (Manteuffel 1929 za: Piskozub 1987). Na potrzeby pracy przyjęto, że do XIII w. włącznie, granice miały wymiar strefowy, a dopiero XIV stulecie jest cezurą, od której można mówić o pojawianiu się granicach linearnych ${ }^{1}$. Należy wspomnieć, że w przypadku braku źródeł historycznych, które umożliwiłyby wyznaczenie granicy, przyjmuje się w nauce polskiej hipotetyczne ustalenie tej granicy wzdłuż lokalnego wododziału - granica ta ma zwykle charakter strefowy (Piskozub 1987).

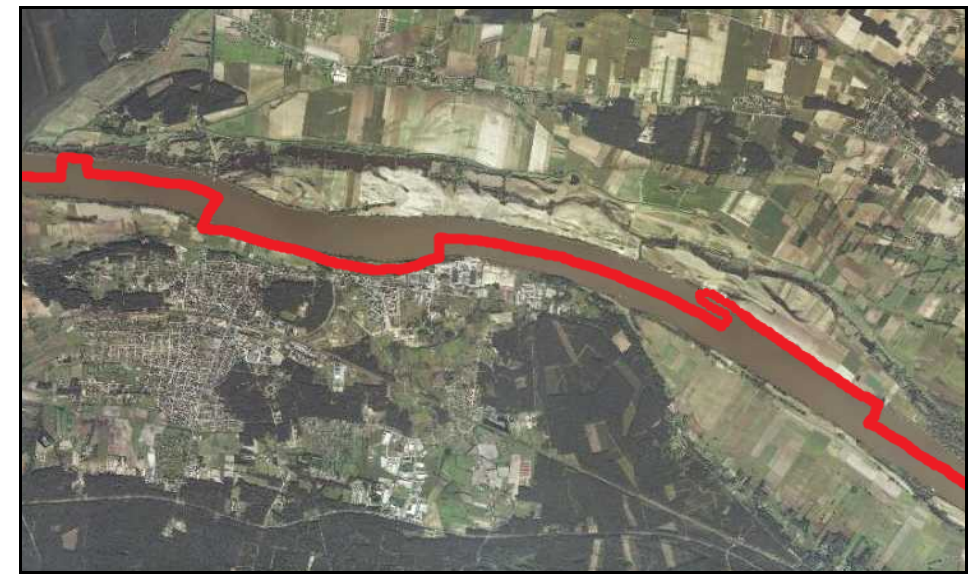

Ryc. 1. Granica powiatów toruńskiego i bydgoskiego w okolicach Solca Kujawskiego Źródło: Geoportal (http://geoportal.gov.pl/)

Na gruncie współczesnej polskiej geografii politycznej granicami rzecznymi zajmował się przede wszystkim Stefan Kałuski (Sobczyński 2008). Należy wymienić dwie jego prace z tego zakresu: Rzeki graniczne a kształtowanie się więzi regionalnych w Europie (1992) oraz Granice polityczne, naturalne i sztuczne anachronizm czy aktualny problem? (1997). Jednakże z zagadnieniami opisywanymi w niniejszym artykule dużo bardziej korespondowały prace Marka Sobczyńskiego: Niezmienność dawnych granic politycznych na obszarze Polski (1984) i Rzeka Prosna jako granica polityczna2. Obie wspomniane publikacje, choć traktujące o granicach politycznych, wnoszą znaczny wkład w zrozumienie przemian krajobrazu administracyjnego Polski.

${ }^{1}$ De facto pierwszą linearną granicą na ziemiach polskich były granice prowincji gnieźnieńskiej z $1136 \mathrm{r}$.

${ }^{2}$ Niepublikowany artykuł dostępny na: http://geopol.geo.uni.lodz.pl/wp-content/up loads/2010/12/prosna.pdf (dostęp: 11.3.2012). 


\section{Granice na Wiśle na tle historycznych podziałów Polski}

\subsection{Granice na Wiśle w średniowieczu}

We wczesnym średniowieczu (VI-VII w.) na ziemiach Polski funkcjonowały wspólnoty terytorialne. Były to skupiska sąsiadujących ze sobą niewielkich osad (lub grodu i osady), których mieszkańcy mieli prawo do wspólnego użytkowania otaczających je obszarów. Na obszarze dzisiejszej Wielkopolski wspólnotę taką określano jako „opole”, natomiast na Mazowszu, a także w południowej i centralnej części ziem polskich jako „osada” (Podwińska 1978). Warto zaznaczyć, że granice opola zwykle miały charakter naturalny i były wyznaczone przez elementy środowiska, które mogły stanowić trudną do pokonania przeszkodę bagna, rzeki, puszcze itp. (Manteuffel, Dowiat 1979).

Określenie roli Wisły, jako rzeki granicznej, w pierwotnych podziałach kraju na terytoria plemienne (IX-X w.) jest stosunkowo łatwe. Wynika to z faktu, że w tamtym okresie Wisła stanowiła oś osadniczą, a nie granicę. Można domniemywać, że jedynie w miejscach, w których granice działów wodnych zbliżały się do Wisły, rzeka mogła stanowić rzeczywistą granicę obszarów plemiennych. Jest to jedynie hipoteza, którą oparto na strefowości ówczesnych granic. Równie dobrze znaczenie Wisły mogło się ograniczać jedynie do przeszkody strategicznej, utrudniającej przemieszczanie się wojsk czy ludności.

Określono trzy takie miejsca, w których linia wododziału, a tym samym naturalnej granicy plemiennej dochodzi do linii Wisły. Patrząc od południa jest to: Wisła Śląska - jako możliwa granica pomiędzy Ślężanami a Wiślanami, obszar na granicy Kotliny Toruńskiej i Doliny Fordońskiej (kolano Wisły w okolicach Bydgoszczy) - jako możliwa granica Polan, Mazowszan i Kaszubów, a także obszar dzisiejszych Żuław Wiślanych (w tamtym czasie jeszcze nie w pełni wykształconych) - jako możliwa granica plemion pruskich z Kaszubami. Analiza mapy Plemiona na ziemiach polskich $w I X-X w$., przedstawionej w książce Zarys historii Polski (Tazbir 1979), daje odmienny rezultat. Wisła jest tam raczej granicą separującą od siebie obszary poszczególnych plemion. Jest to szczególnie widoczne na odcinku Wisły Pomorskiej, która oddzielała plemiona Pomorzan od Prusów. Podobny, liniowy przebieg granicy na ostatnim odcinku dolnej Wisły jest przedstawiony na mapie Powstanie państwa polskiego w Ilustrowanym atlasie historii Polski (Olczak, Sienkiewicz 2006).

Jak podaje Z. Gloger w Geografii historycznej ziem dawnej Polski (1991), w X w. Wisła w swym dolnym biegu stanowiła granicę pomiędzy „Pomorzem 
polskim” a „Pomorzem pruskim”. Biegła ona brzegiem rzeki ${ }^{3}$ od ujścia do Bałtyku aż po jej prawobrzeżny dopływ - rzekę Ossę (dzisiejsza Osa). Na południu Polski natomiast, Wisła na niewielkim odcinku, który współcześnie można określić jako Strumień-Goczałkowice, stanowiła granicę pomiędzy Śląskiem a ziemią krakowską. W XI w. ten sam odcinek, rozszerzony do ujścia Przemszy, był krótkotrwałą granicą z Czechami. W tym samym okresie znaczna część biegu Wisły Kujawskiej i Pomorskiej stanowiła północną granicę państwa polskiego. Na mapie Polska za panowania pierwszych Piastów (Olczak, Sienkiewicz 2006) granicę liniową pomiędzy Polską a Prusami w obrębie delty Wisły przesunięto z Wisły na Nogat.

Kościelny podział ziem polskich w XI w. na diecezje tylko w jednym przypadku wykorzystywał Wisłę jako granicę. Rozdzielała ona ziemię diecezji kołobrzeskiej od ziem diecezji gnieźnieńskiej. Linia podziału zaczynała swój bieg na północ od Fordonu i biegła do ujścia rzeki Osy, gdzie zaczynało się terytorium pruskie.

\subsection{Granice na Wiśle w okresie rozbicia dzielnicowego}

Podczas trzech stuleci rozbicia dzielnicowego Wisła na pewnych odcinkach swojego biegu stanowiła granicę międzydzielnicową i międzypaństwową. Okresowi temu należy poświęcić dodatkową uwagę, gdyż jak pisze A. Piskozub (1987), to właśnie w tym czasie „szukać winniśmy pierwotnego obrazu podziału terytorialnego kraju, utrwalonego później w podziale na województwa przedrozbiorowej Polski”. Podział polityczny ziem polskich w omawianym okresie ilustruje rycina 2. W XII w., wspomniany wcześniej odcinek Strumień-Goczałkowice oznaczany jest w atlasach historycznych jako granica pomiędzy Śląskiem a dzielnicą senioralną (a dokładniej - ziemią krakowską). Kolejny odcinek Wisły jako rzeki granicznej zaczynał się za Fordonem i biegł aż do Bałtyku. Od Fordonu do ujścia rzeki Osy była to granica między Mazowszem a północnym krańcem dzielnicy senioralnej (Kujaw) i Pomorzem Gdańskim. Od ujścia Osy, Wisłą i dalej Nogatem biegła granica między Pomorzem Gdańskim a Prusami.

W kolejnym, XIII w., odcinek Wisły Strumień-Goczałkowice znalazł się w całości w Księstwie Opolsko-Raciborskim. Cały bieg Wisły Kujawskiej stanowił granicę międzydzielnicową: od ujścia Skrwy do ujścia Drwęcy rozdzielał Kujawy od ziemi dobrzyńskiej, a od ujścia Drwęcy po ujście Osy rozdzielał Kujawy i Pomorze Gdańskie od ziemi chełmińskiej. Warto zaznaczyć, że rola rzeki jako granicy kujawsko-mazowieckiej jest podważana w literaturze przed-

${ }^{3}$ Z. Gloger nie podaje, którym brzegiem rzeki biegła owa granica. W kontekście opisanych wcześniej argumentów o strefowości granic, informację przedstawioną przez autora można traktować jedynie jako ciekawostkę historyczną. 
miotu. Jak wykazały badania własnościowo-osadnicze, rycerstwo mazowieckie posiadało własności ziemskie na lewym brzegu Wisły, przy jednoczesnym braku takich własności przez posiadaczy z zachodnich części Polski. Faktyczna linia graniczna kształtowała się zatem nie na Wiśle, lecz w głębi Kujaw ${ }^{4}$ (Śliwiński 1989). Ostatni odcinek Wisły Pomorskiej stanowił granicę pomiędzy Pomorzem Gdańskim a Państwem Zakonu Krzyżackiego.

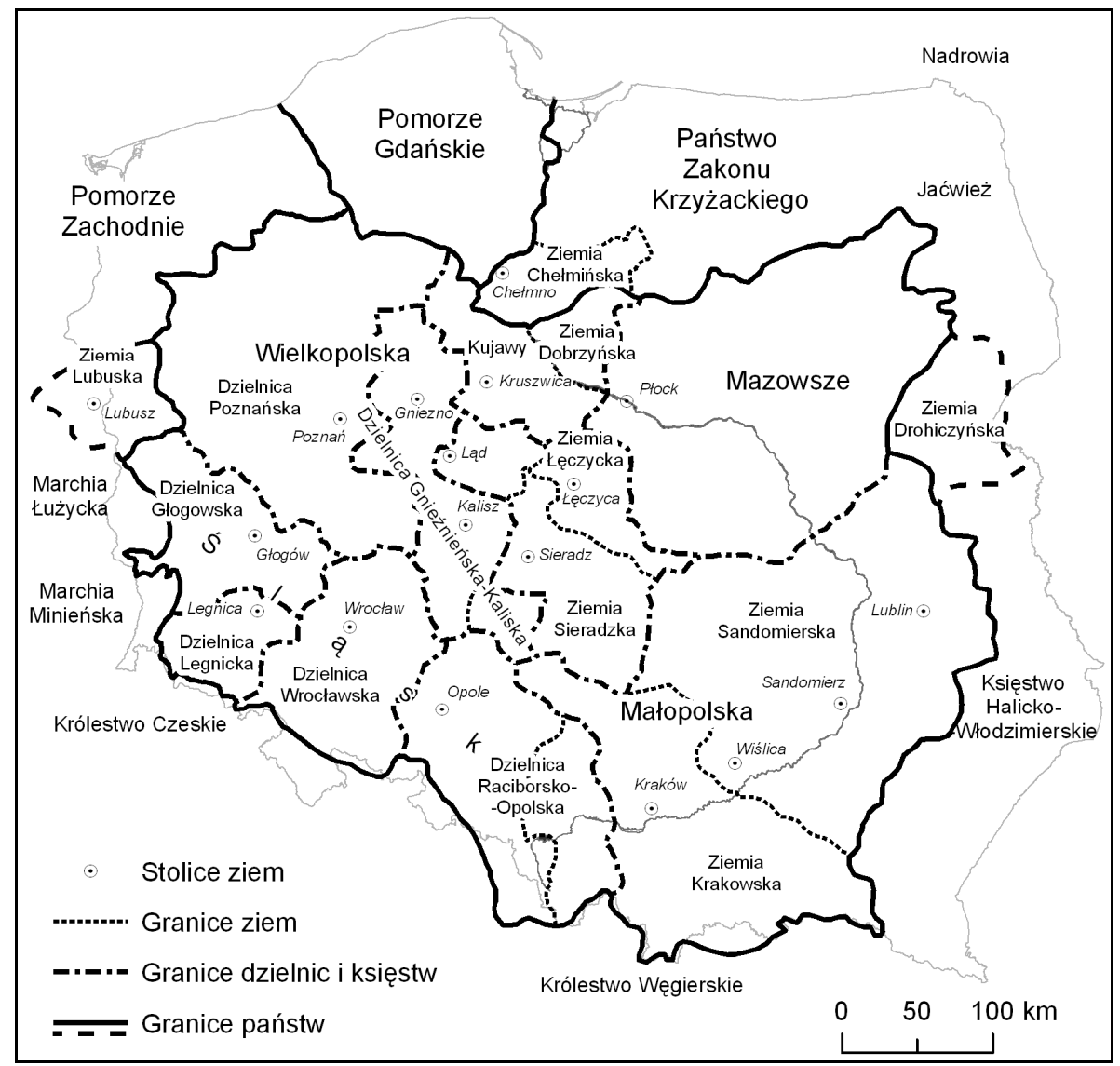

Ryc. 2. Podział polityczny ziem polskich w epoce feudalnej Źródło: opracowanie własne na podstawie: M. Sobczyński, M. Kulesza (2006)

W XIII w. Wisła była także barierą cywilizacyjną - ówczesną granicą pomiędzy Europą a Azją. Świadczy o tym mapa obiektów architektury romańskiej, dla których Wisła była wschodnią granicą występowania (Piskozub 1995, s. 39).

${ }^{4}$ Przebieg granicy kształtował się mniej więcej wzdłuż linii: Kowal, Brześć Kujawski, ok. Kościelnej Wsi, Seroczki-Chróstowo, Służewo-Grabie, Wyszogród. 
Pod koniec okresu rozbicia dzielnicowego (przełom XIII i XIV w.) przebieg granic na Wiśle przedstawiał się następująco. Odcinek Oświęcim-Skawina stanowił granicę pomiędzy Królestwem Polskim (ziemia krakowska) a ziemiami lennymi Królestwa Czeskiego (Księstwo Oświęcimsko-Zatorskie). Od ujścia Drwęcy po okolice wsi Zła Wieś (na północ od Fordonu) Wisła była granicą pomiędzy Królestwem Polskim a Państwem Zakonu Krzyżackiego. Za czasów Kazimierza Wielkiego, granica Księstwa Płockiego, będącego lennem czeskim, oparła się czasowo na Wiśle: od okolic Wyszogrodu po ujście Skrwy.

Rozpatrując kościelny podział kraju w XIII w., można zauważyć, że Wisła stanowiła na wielu swych odcinkach granicę diecezjalną. Początkowy bieg Wisły, w Beskidzie Śląskim, jak i odcinek Strumień-Goczałkowice był granicą pomiędzy diecezjami wrocławską a krakowską. Kolejny odcinek graniczny zaczynał się w okolicach Warszawy i rozciągał się do ujścia rzeki Mołtawy była to granica archidiakonatu czerskiego (należącego do diecezji poznańskiej) i diecezji płockiej. Od ujścia Skrwy aż po Bałtyk Wisła stanowiła wschodnią granicę diecezji włocławskiej.

Na rolę graniczną Wisły w Polsce piastowskiej można spojrzeć pod innym kątem niż tylko podziału na jednostki terytorialne. Górna i środkowa Wisła wraz z odcinkami rzek: Noteci, Obry i Odry wyznaczały tzw. obszar rdzeniowy ów-

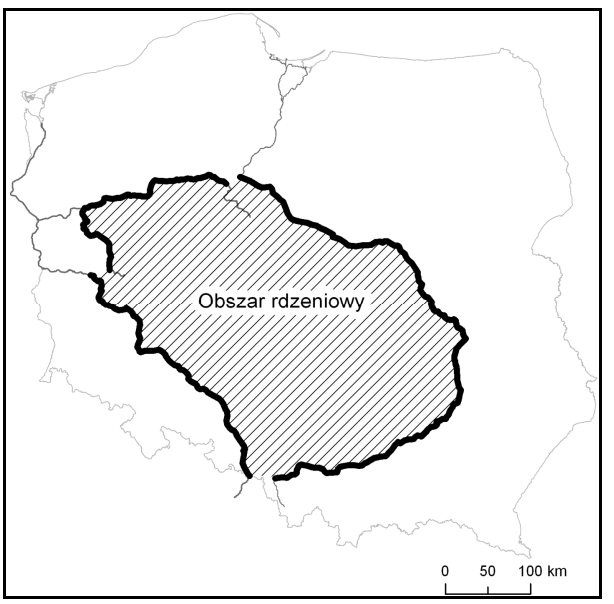

Ryc. 3. Obszar rdzeniowy Polski piastowskiej

Źródło: opracowanie własne na podstawie: A. Piskozub (1987) czesnej Polski (ryc. 3), który zamieszkiwała większość ludności państwa i na którym znajdowały się jego najważniejsze ośrodki. Kształt przedstawionej sytuacji przestrzennej wynikał przede wszystkim ze znaczenia obronnego. Obszar rdzeniowy, otoczony pierścieniem rzek i zabagnionymi dolinami, w znacznym stopniu podnosił poziom bezpieczeństwa jego mieszkańców. Do wnętrza tego pierścienia prowadziły zaledwie trzy drogi. Pierwsza, od południa, prowadziła przez Bramę Morawską, a dokładniej pomiędzy górnymi biegami Wisły i Odry. Drugi szlak, od strony północnej, prowadził bagnistą pradoliną rozciągającą się pomiędzy Brdą a Notecią. Trzeci dostęp, z zachodu, utrudniał skomplikowany układ hydrograficzny rzek Odry, Obry i Obrzycy. Zatem obszar rdzeniowy był chroniony niemal nieprzerwaną, trudno przekraczalną barierą wodną. Wzdłuż całego jej obwodu, w miejscach, w których znaj- 
dowały się brody czy inne dogodne przeprawy, zostały wybudowane strzegące ich grody. Rola Wisły w ochronie obszaru rdzeniowego była bardzo duża. Wielki łuk Wisły, który rozciągał się od ziemi krakowskiej aż po Kujawy, był znaczącą przeszkodą strategiczną, powstrzymującą pochody wojenne. Jego południowo-wschodni odcinek stanowił barierę dla najazdów stepowych koczowników, a także tych idących z Rusi. Część północno-wschodnia natomiast blokowała najazdy Prusów, Jadźwingów i Litwinów. Strategiczne znaczenie obszaru rdzeniowego utrzymało się blisko cztery stulecia i dopiero podpisanie unii personalnej z Litwą pod koniec XIV w. otworzyło drogę do przesuwania się polskiego osadnictwa na wschodnią część dorzecza Wisły (Piskozub 1987).

\subsection{Granice na Wiśle za panowania Jagiellonów i w okresie przedrozbiorowym}

W okresie panowania Jagiellonów, zmiany, jakie zaszły w układzie geopolitycznym, spowodowały włączenie rozdzielonych ziem Księstwa Oświęcimskiego i Zatorskiego do Królestwa Polskiego. Tym samym granica polsko-czeska na Wiśle przesunęła się na zachód, na odcinek: Goczałkowice (rzeka Biała)-Oświęcim. Podkreślić trzeba, że wspomniany odcinek ma charakter granicy tradycyjnej. Początków jego kształtowania można się doszukiwać już w XII w., lecz dopiero przebieg ukształtowany w $1474 \mathrm{r}$. był tym ostatecznym - tym, który wrył się głęboko w krajobraz administracyjny Polski. Obowiązywał bowiem jako granica państwowa Polski przedrozbiorowej, następnie granica państw zaborczych, by przekształcić się, w okresie międzywojennym, w granicę województw: krakowskiego i śląskiego (Piskozub 1987). Wracając do opisu przebiegu granic w XV i XVI w., to niewielki odcinek Wisły, od ujścia Skrwy po ujście Drwęcy stanowił czasową granicę z lennym Księstwem Mazowieckim. Od ujścia Drwęcy Wisła była, tak jak wcześniej, granicą z państwem krzyżackim, jednakże po podpisaniu pokoju toruńskiego w $1466 \mathrm{r}$. jej przebieg znacznie się zmienił. Po włączeniu do Polski Prus Królewskich granica na Wiśle dotyczyła zaledwie krótkiego odcinka rozciągającego się od ujścia Osy po Kwidzyn. Była to granica z lennymi Prusami Książęcymi, która utrzymała się do $1657 \mathrm{r}$.

Proces podziału Polski na województwa został zapoczątkowany już w XIV w. Był to proces ewolucyjny trwający nieprzerwanie do 1569 r. Według A. Piskozuba (1987) była to cezura, od której podział administracyjny kraju nie zmienił się, z jednym wyjątkiem ${ }^{5}$, aż do okresu rozbiorów. W podziale administracyjnym Rzeczypospolitej przedrozbiorowej Wisła stanowiła zarówno granicę międzypaństwową, jak i wojewódzką. Poniższy opis został opracowany na pod-

${ }^{5}$ W 1768 r. z województwa kaliskiego wydzielono nowe województwo gnieźnieńskie. 
stawie mapy Polska w roku 1771 (Babirecki 1895) i atlasów historycznych, jego ilustrację stanowi zaś rycina 4.

Tak jak już napisano wcześniej, odcinek Goczałkowice-Oświęcim stanowił granicę państwową - początkowo z Królestwem Czeskim. Za Oświęcimiem Wisła płynęła przez województwo krakowskie do okolic Koszyc, gdzie zaczynało się województwo sandomierskie. W okolicach Zawichostu rozpoczynał się graniczny odcinek Wisły pomiędzy województwami: sandomierskim i lubelskim. Według M. Janiszewskiego (1959, s. 72):

Granica została wyznaczona dotychczasową arterią komunikacyjną - Wisłą. Ten błąd geograficzny Jagiellonów trwa do dzisiejszego dnia. Rzeka, która powinna łączyć te obszary, zaczęła je dzielić.

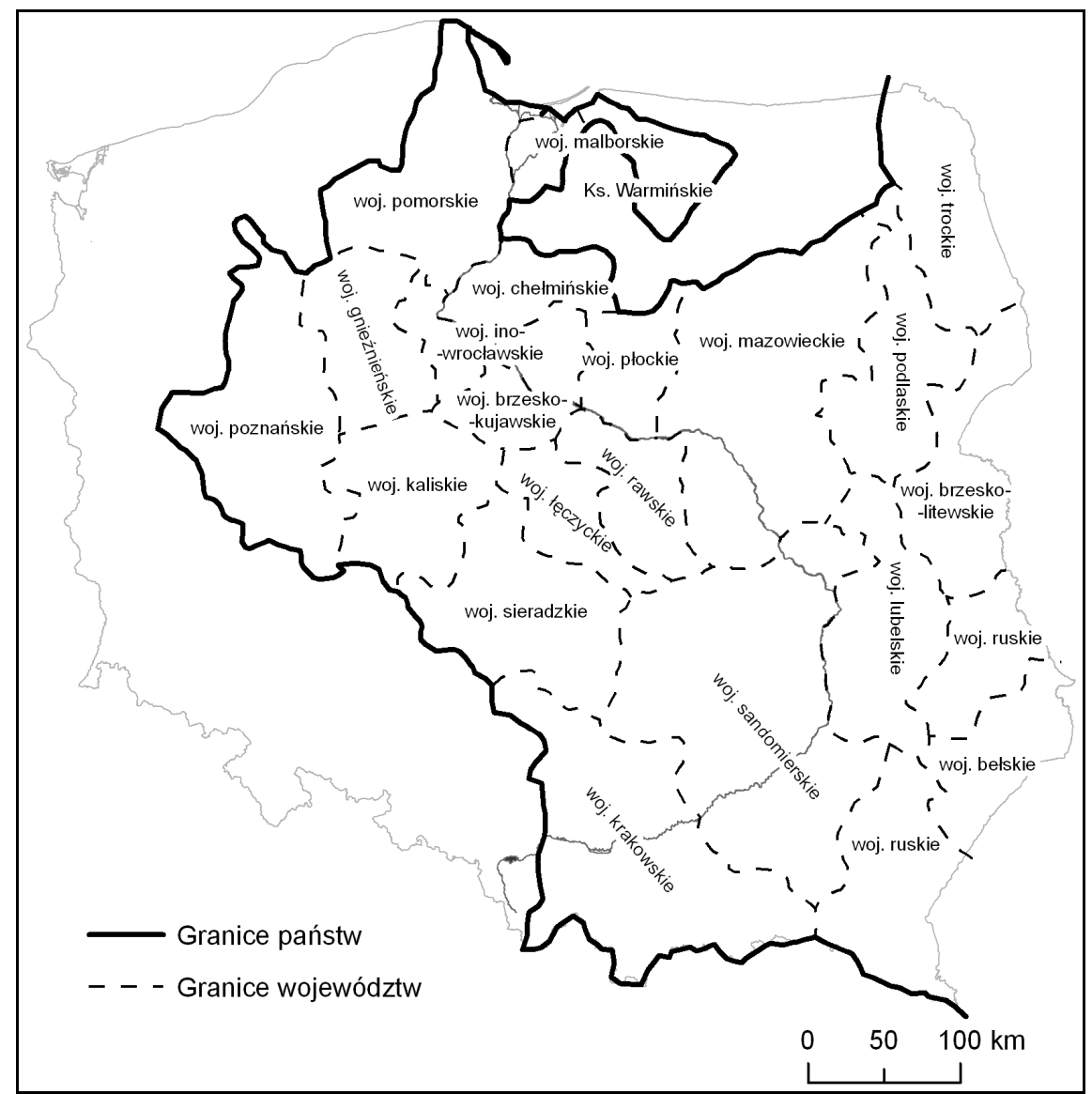

Ryc. 4. Podział przedrozbiorowy ziem polskich na województwa Źródło: opracowanie własne na podstawie: A. Piskozub (1987, s. 114) i M. Sobczyński (1994, s. 104) 
Była to pierwsza, trwała granica międzywojewódzka, której przebieg został wyznaczony wzdłuż Wisły (Piskozub 1987). Graniczny odcinek Wisły kończył się przy ujściu Wieprza, gdzie rzeka płynęła dalej przez województwo sandomierskie. W okolicach Maciejowic i Magnuszewa Wisła wpływała na obszar województwa mazowieckiego. Od ujścia Bzury, naprzeciw Wyszogrodu, Wisła znów przyjmowała rolę granicy wojewódzkiej. Do ujścia Mołtawy, będącego jednocześnie granicą z województwem płockim, stanowiła granicę województw: mazowieckiego i rawskiego. Za ujściem Mołtawy do ujścia Skrwy rozciągało się województwo płockie, dla którego Wisła była także granicą z województwem rawskim. Przyczyn wyznaczenia Wisły jako granicy wojewódzkiej tych trzech mazowieckich jednostek podziału administracyjnego można się dopatrywać w dawnym przebiegu granic dzielnic książęcych. Następnie od okolic Płocka, na lewym brzegu rzeki, po okolice Włocławka (ujście Zgłowiączki) rozciągało się wzdłuż Wisły województwo brzesko-kujawskie. Na prawym brzegu natomiast znajdowała się ziemia dobrzyńska, będąca wschodnią częścią województwa inowrocławskiego. Odcinek Wisły od ujścia Drwęcy do ujścia Osy stanowił zachodnią granicę województwa chełmińskiego; do okolic położonej na lewym brzegu wsi Zła Wieś była to granica $\mathrm{z}$ województwem inowrocławskim, a dalej na północ $-\mathrm{z}$ województwem pomorskim. Odcinek od ujścia Osy do okolic Kwidzyna stanowił granicę państwową z Prusami Książęcymi. Ostatnia część biegu Wisły była granicą między województwami pomorskim a malborskim. Zaznaczyć trzeba, że w przypadku czterech ostatnich województw (inowrocławskiego, chełmińskiego, pomorskiego i malborskiego) granice na Wiśle można uznać za relikty wcześniejszych jednostek składowych Pomorza Wschodniego (Piskozub 1987).

\subsection{Granice na Wiśle w okresie zaborów}

Sytuacja geopolityczna, która nastała po pierwszym zaborze Polski, wyznaczyła Wiśle nową rolę. Do 1772 r. rzeka płynęła niemal w całości swego biegu przez terytorium Polski, natomiast po pierwszym rozbiorze jej górny bieg stał się granicą polityczną, a dolny przeszedł pod władanie innego kraju (z wyjątkiem Torunia i okolic Gdańska).

Źródła Wisły, tak jak cały karpacki bieg Wisły, leżały na terytorium Austrii. Dopiero od miejscowości Strumień Wisła przyjmowała rolę granicy politycznej, rozciągającej się aż do Zawichostu (ryc. 5): od Strumienia do Oświęcimia była to granica prusko-austriacka, a dalej, za ujściem Przemszy, granica polsko-austriacka. Po raz pierwszy w historii górny bieg Wisły stał się barierą polityczną, która w sztuczny sposób dzieliła Małopolskę. Zintegrowany pierwotnie pod wieloma względami (narodowościowymi, językowymi, religijnymi i gospodarczy- 
mi) obszar został przecięty. Początkowo granica miała charakter linii demarkacyjnej. Z czasem jednak stała się właściwą granicą państwową, co było wynikiem zamierzonej polityki państw zaborczych, nakierowanej na pogłębienie antagonizmów pomiędzy mieszkańcami obu brzegów. Proces ten pogłębiał fakt, że opisywany obszar leżał na obszarze pogranicznym, na którym ze względów strategicznych celowo hamowano rozwój ekonomiczny (Rajman, Zioło 1992). W opisywanym okresie górny bieg Wisły był nieuregulowany. W odniesieniu do treści artykułu ma to o tyle duże znaczenie, że rzeka, nieujęta w ryzy przez człowieka, ma tendencje do zmian swojego koryta. W przypadku, gdy bieg rzeki jest równoznaczny z przebiegiem linii granicznej, prowadzi to do nieuchronnych konfliktów granicznych wywoływanych zarówno przez naturalne, jak i sztuczne zmiany. Na granicy polsko-austriackiej było wiele takich konfliktów, wśród których najlepiej udokumentowany został spór o prace regulacyjne prowadzone przez Austriaków pod Krakowem w latach 1780-1782 (Stoksik 1990). Od Zawichostu po ujście Drwęcy Wisła płynęła przez okrojone terytorium Rzeczypospolitej; granice wojewódzkie na Wiśle, ustalone przed okresem zaborów, nie uległy zmianom. Granica polsko-pruska rozcinała Wisłę przy ujściu Drwęcy, przy czym Torun, leżący już na pruskim brzegu, pozostał przy Polsce. Podobnie było w przypadku Gdańska, który pozostał przy Polsce, a Wisła stanowiła tam wschodnią granicę z Prusami.

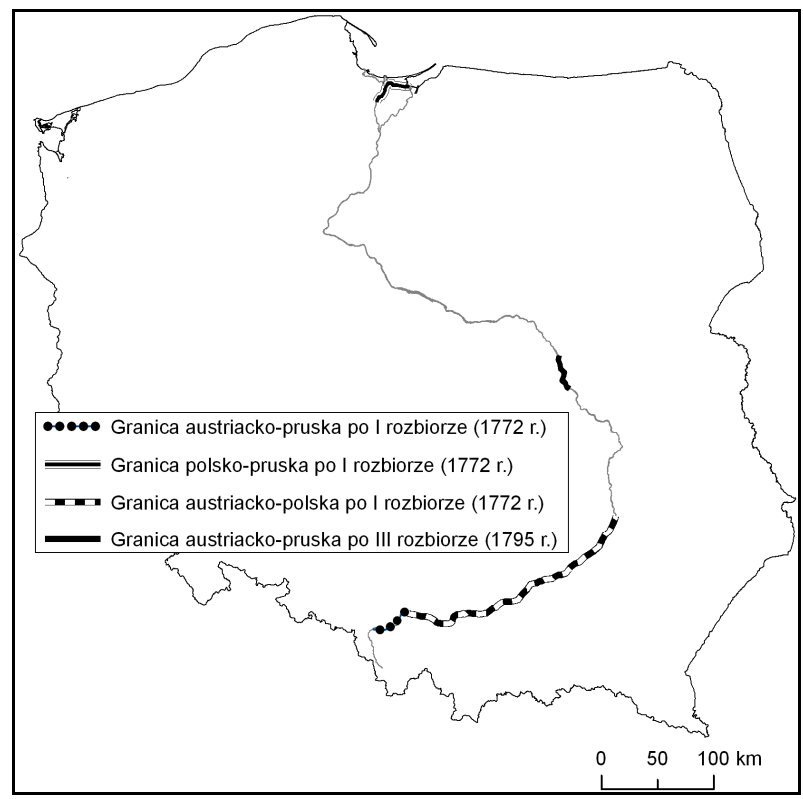

Ryc. 5. Granice na Wiśle w okresie zaborów Źródło: opracowanie własne na podstawie: E. Olczak (2003) 
Drugi rozbiór Polski, w kontekście Wisły, zmienił sytuację jedynie w dolnym biegu rzeki. Gdańsk i Toruń zostały włączone do zaboru pruskiego, a granica prusko-polska przesunęla się w górę Wisły za Wyszogród. Dwa lata później dokonano trzeciego rozbioru kraju, który włączył pozostałe ziemie polskie, przez które przepływała Wisła, do zaboru pruskiego i austriackiego. Odcinek Wisły od ujścia Pilicy do ujścia Świdra stał się granicą zaborczą prusko-austriacką (ryc. 5).

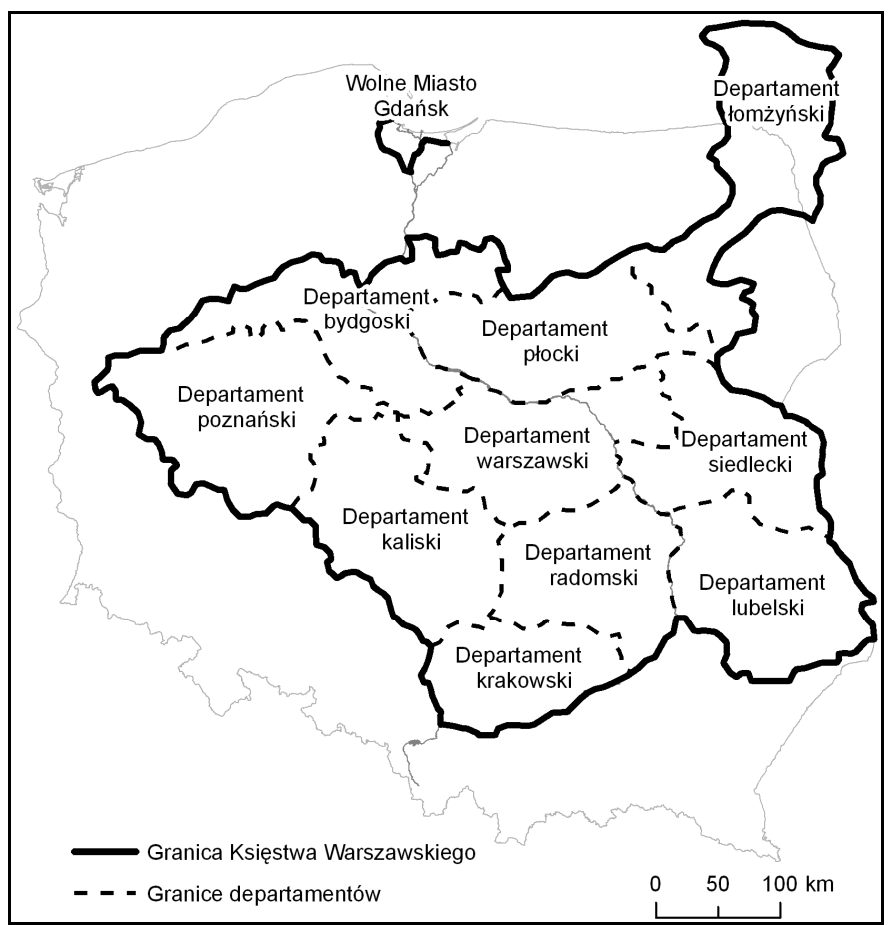

Ryc. 6. Podział administracyjny Księstwa Warszawskiego (1807-1815) Źródło: opracowanie własne na podstawie: E. Olczak (2003)

W 1807 r. utworzono, podporządkowane Napoleonowi, Księstwo Warszawskie, które podzielone zostało na departamenty (ryc. 6). Od ujścia Przemszy do Zawichostu Wisła była granicą Księstwa Warszawskiego i Cesarstwa Austriackiego. Na polskim brzegu rzeki, do ujścia rzeki Czarnej był to departament krakowski, a dalej departament radomski, który za Zawichostem graniczył z departamentem lubelskim. Od ujścia Wieprza Wisła była granicą departamentów radomskiego i siedleckiego. Za ujściem Pilicy zaczynał się departament warszawski, który do ujścia Świdra graniczył poprzez Wisłę z departamentem siedleckim. Od ujścia Bugu-Narwi do ujścia Skrwy Lewej Wisła stanowiła granicę 
departamentów warszawskiego i płockiego. Za ujściem Skrwy, po ujście Drwęcy, Wisła była granicą departamentów płockiego i bydgoskiego. Od ujścia Drwęcy Wisła płynęła przez departament bydgoski do okolic wsi Zła Wieś, gdzie znów stawała się granicą polityczną pomiędzy Księstwem Warszawskim, a Królestwem Pruskim. Od 1807 r. funkcjonowało też autonomiczne Wolne Miasto Gdańsk, które było odgrodzone na wschodzie od Prus linią Wisły: od okolic lewobrzeżnego Steblewa i dalej - częściowo jednym z jej ujściowych ramion - Szkarpawą.

Po ustaleniach Kongresu Wiedeńskiego zmianie uległa część granic wytyczonych na Wiśle. Od ujścia Przemszy do okolic Niepołomic (ujście potoku Kościelnickiego) Wisła stanowiła granicę pomiędzy Rzeczpospolitą Krakowską a Cesarstwem Austriackim. Za Niepołomicami granica polityczna ciągnąca się do Zawichostu nie uległa zmianie. Od Zawichostu po miejscowość Otłoczyn (ujście Tążyny) Wisła przepływała przez Królestwo Polskie. Jego podział wewnętrzny był taki sam jak w Księstwie Warszawskim, z dwoma wyjątkami. Dawny departament radomski został przemianowany na województwo sandomierskie, a od ujścia Świdra do Otłoczyna Wisła stanowiła granicę między województwami mazowieckim i płockim. Za ujściem Tążyny Wisła wpływała na terytorium Królestwa Pruskiego. Od ujścia cieku, który na współczesnej mapie został zidentyfikowany jako Kanał Zielona Struga (lub jego bezpośrednich okolicach), Wisła stanowiła granicę między Królestwem Pruskim a podporządkowanym mu Wielkim Księstwem Poznańskim. Bieg tej granicy po Wiśle kończył się na wschód od wsi Zła Wieś.

\subsection{Granice na Wiśle w okresie II Rzeczypospolitej}

Okres zaborów spowodował całkowitą zmianę struktur terytorialnych ziem polskich, dlatego też po uzyskaniu niepodległości w 1918 r. niezwłocznie przystąpiono do ich reformy. Nowy, trójstopniowy podział administracyjny II Rzeczypospolitej kształtował się w latach 1918-1922. Powstające państwo miało dzielić się województwa, powiaty i gminy (miejskie i wiejskie). Należy zaznaczyć, że podział na województwa traktowany był początkowo jako tymczasowy - miał ulec zmianie w czasach późniejszych (Mielcarek 2008). Po ostatecznym ukształtowaniu się zewnętrznych granic II Rzeczypospolitej niemalże cały bieg Wisły znalazł się w granicach Polski. Wyjątkiem był odcinek rozciągający się na północ za Grudziądzem do samego ujścia Wisły. Był on po części linią graniczną, a częściowo należał do Wolnego Miasta Gdańsk. Do analizy przebiegu granicy pomiędzy Polską, Prusami Wschodnimi i Wolnym Miastem Gdańsk (ryc. 7) użyto map Wojskowego Instytutu Geograficznego (WIG, 1930-1939). Granica niemiecka dochodziła do Wisły z prawego brzegu, na wysokości wsi 
Mały Wełcz, i biegła na północ prawobrzeżnym podwalem (od strony rzeki) do należącego do Polski portu rzecznego w Korzeniewie (daw. Kurzybrak). W Pastwie (naprzeciw Gniewu) granica przekraczała linię wału i wchodziła na terytorium Prus. Był to niewielki obszar, obejmujący pięć wsi (Borztych, Janowo, Kramrowo, Nowe Lignowy i Pólko Małe), który przydzielono Polsce po plebiscycie w 1920 r. Kilka kilometrów dalej na północ, w Szalwinku (daw. Schadewinkel), granica znów wracała pod prawobrzeżne podwale (od strony Wisły) i biegła nim aż do Cypla Mątowskiego. W tym miejscu spotykały się granice Polski, Niemiec i Wolnego Miasta Gdańsk. Część granicy Polski z Wolnym Miastem Gdańsk przebiegała Wisłą: od Cypla Mątowskiego do wysokości prawobrzeżnej wsi Boręty, gdzie skręcała pod kątem prostym na zachód; natomiast południowo-wschodnia granica Wolnego Miasta Gdańsk z Prusami Wschodnimi przebiegała Nogatem.

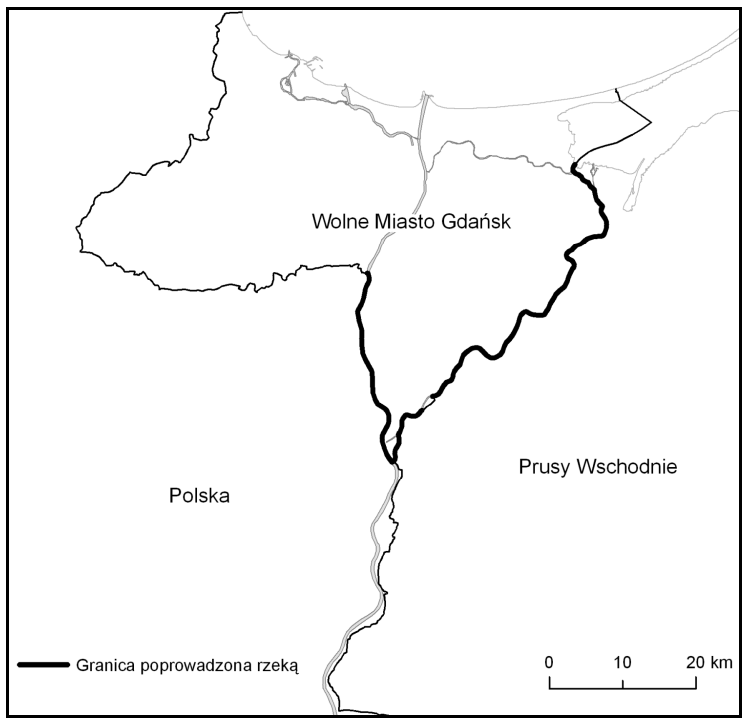

Ryc. 7. Przebieg granicy pomiędzy Polską, Prusami Wschodnimi i Wolnym Miastem Gdańsk

Źródło: opracowanie własne na podstawie map WIG (1930-1939)

Podział administracyjny II Rzeczypospolitej ilustruje rycina 8. W opisywanym okresie Wisła w znacznej części swego biegu pełniła funkcję granicy wojewódzkiej (WIG, 1930-1939). Rzeka rozpoczynała swój bieg w województwie śląskim i dopiero na odcinku od ujścia rzeki Białej do ujścia Przemszy (w Oświęcimiu) była granicą z województwem krakowskim. Kolejny odcinek graniczny zaczynał się za Niepołomicami, a dokładniej od ujścia potoku Kościelnickiego (nawiązanie do wschodniej granicy Rzeczypospolitej Krakowskiej); rzeka rozdzielała 
województwa: kieleckie i krakowskie. Następnie od okolic Dymitrowa (na zachód od Baranowa Sandomierskiego) do Zawichostu rzeka była granicą województwa kieleckiego oraz lwowskiego. Od Zawichostu do ujścia Pilicy Wisła stanowiła natomiast granicę między województwami kieleckim i lubelskim. Kolejny odcinek granicy wojewódzkiej, pomiędzy województwami warszawskim i lubelskim, rozciągał się od ujścia Pilicy do okolic Ostrówka (naprzeciwko Góry Kalwarii).

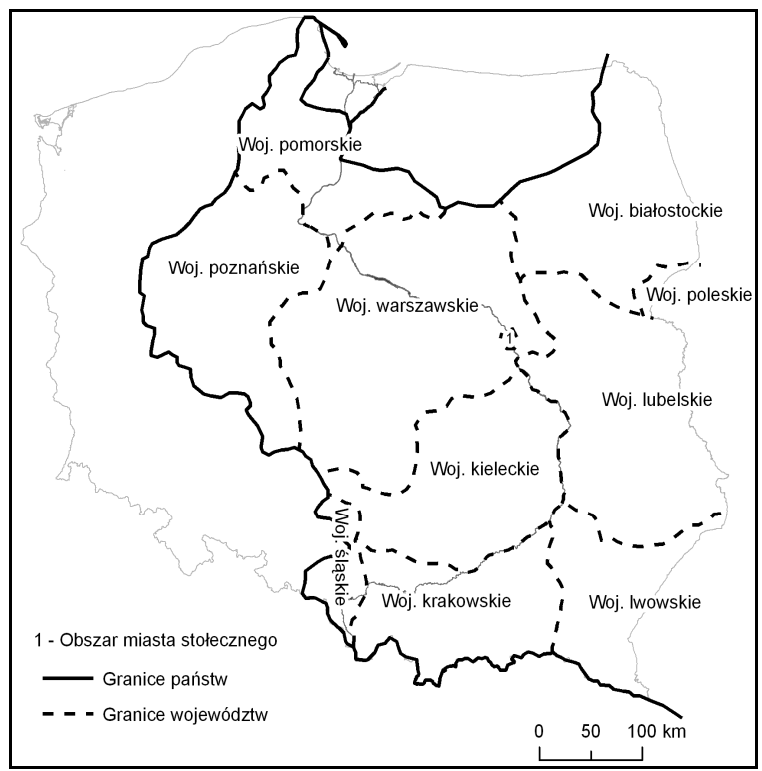

Ryc. 8. Podział na województwa ziem polskich w okresie międzywojennym Źródło: opracowanie własne na podstawie: M. Sobczyński (1994)

Idąc dalej przez Mazowsze, rzeka rozcinała województwo warszawskie i obszar miasta stołecznego. Za ujściem Tążyny (okolice Otłoczyna) Wisła wpływała do województwa pomorskiego, gdzie od ujścia Kanału Zielona Struga (na zachód od Torunia) po Złą Wieś była granicą z województwem poznańskim. Niewielki fragment tego odcinka granicy, na wysokości Solca Kujawskiego, charakteryzował się specyficznym przebiegiem linii granicznej (ryc. 9). Trudno określić jednoznacznie, jaka była przyczyna takiego kształtu. Najbardziej prawdopodobne są dwie hipotezy. Pierwsza z nich odnosi się do przebiegu pierwotnego koryta rzeki, druga natomiast do stosunków własnościowych. Brak dokładnych map z wcześniejszych okresów utrudnia wyjaśnienie tej historyczno-geograficznej zagadki. Należy jedynie nadmienić, że podobny przebieg granicy dotyczył podziału administracyjnego z 1975 r. (także granica wojewódzka) i można go odnaleźć w aktualnym podziale jako granica powiatowa. 


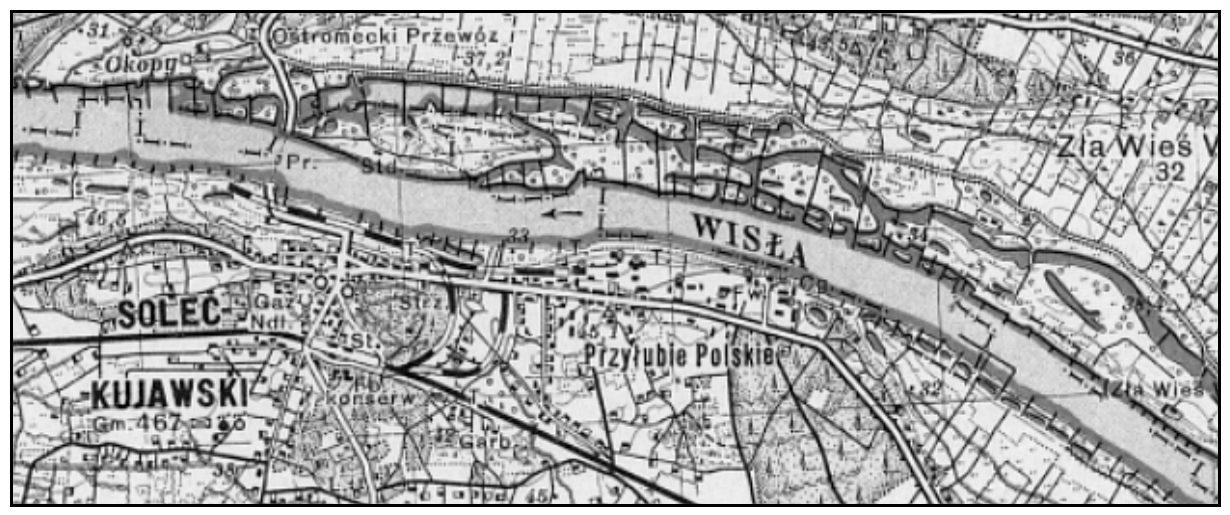

Ryc. 9. Granica między województwami poznańskim i pomorskim w okolicach Solca Kujawskiego

Źródło: Mapa WIG P36 S26 Bydgoszcz, skala 1:1 00000

(WIG, 1930-1939)

Kilka dni przed wybuchem drugiej wojny światowej podpisano w Moskwie pakt Ribbentrop-Mołotow, który wyznaczał linię podziału Polski pomiędzy III Rzeszę i ZSRR. Znaczna część tej granicy miała przebiegać Wisłą, od ujścia Sanu po ujście Bugu-Narwi. Pierwszego września 1939 r. Polska została zaatakowana przez faszystowskie Niemcy i po kilku tygodniach podbita. Wprowadzony przez okupanta nowy podział administracyjny na pewnych odcinkach opierał się na Wiśle. Cała Wisła Śląska i część biegu Wisły Małopolskiej znalazły się na terytorium Rzeszy Niemieckiej, w okręgu Górny Śląsk. W okolicach wsi Przewóz (na południe od Alwerni) rzeka wpływała na obszar Generalnego Gubernatorstwa, do dystryktu krakowskiego. Za Nowym Korczynem Wisła stawała się granicą administracyjną dystryktów krakowskiego i radomskiego. Od ujścia Sanu do okolic Pawłowice (naprzeciwko Kozienic) rozdzielała od siebie dystrykty radomski i lubelski. Tam też rozpoczynał się dystrykt warszawski, którego granicą, do ujścia Pilicy, była również Wisła. W okolicach Palmir, za Warszawą, rzeka ponownie wpływała na terytorium Rzeszy. Od ujścia Ryksy (między Wyszogrodem a Kępą Polską) do Otłoczyna rozdzielała lewobrzeżny okręg Kraj Warty od prawobrzeżnych okręgów Prus Wschodnich (do okolic Dobrzynia nad Wisłą) i Gdańsk-Prusy Zachodnie. W ostatnim ze wspomnianych okręgów Wisła była granicą rejencji bydgoskiej i kwidzyńskiej od południowych krańców Grudziądza po wieś Kozielce (na północ od Nowego), a także gdańskiej i kwidzyńskiej (Kozielec - ujście Nogatu - okolice Jazowej nad Nogatem). Tak szczegółowy opis możliwy był dzięki wykorzystaniu niemieckiej mapy obszaru interesów niemieckich (Das deutsche Interessengebiet, 1939/ 1940). 


\subsection{Granice na Wiśle w okresie Polski Ludowej}

Po zakończeniu drugiej wojny światowej przystąpiono do odbudowy i reorganizacji podziału administracyjnego kraju. W pierwszym, powojennym podziale (ryc. 10), rola Wisły jako granicy wewnętrznej była znaczna, szczególnie w dolnym i środkowym biegu. Od źródeł po ujście Białej sytuacja była analogiczna do stanu sprzed wybuchu wojny. Wisła rozpoczynała swój bieg w województwie śląskim, a od ujścia Białej do ujścia Przemszy była granicą z województwem krakowskim. Następnie płynęła przez województwo krakowskie, do okolic Jaksic (naprzeciwko ujścia Raby), gdzie rozpoczynał się kolejny graniczny odcinek biegu - z województwem kieleckim. Od ujścia rzeki Breń aż po Zawichost Wisła była granicą województw kieleckiego i rzeszowskiego ${ }^{6}$. Od Zawichostu natomiast, po ujście Wieprza, województwo kieleckie sąsiadowało z lubelskim, poza niewielkim odcinkiem rozciągającym się od okolic Zastowa Polanowskiego po okolice miejscowości Gołąb, gdzie granica wchodziła w głąb lewego brzegu. Za ujściem Wieprza do ujścia Pilicy województwo kieleckie graniczyło z warszawskim. Pomiędzy Karolewem a wsią Dąb Wielki (koło Dobrzynia nad Wisłą) rzeka opuszczała województwo warszawskie i wypływała do województwa pomorskiego, przez które płynęła do okolic wsi Mały Wełcz. Tam zaczynało się województwo gdańskie, które jedynie na krótkim odcinku Wisły graniczyło z województwem pomorskim - od wspomnianej wsi Wełcz na prawym brzegu do okolic wsi Kozielec na lewym brzegu. W kolejnym podziale administracyjnym, wprowadzonym zaledwie cztery lata później (1950 r.), rola Wisły jako granicy międzywojewódzkiej nie uległa żadnej zmianie w całym swym biegu.

Podział administracyjny kraju z 1975 r. likwidował powiaty, a w miejsce dużych województw powołano liczniejsze, acz zdecydowanie mniejsze jednostki tego samego stopnia (ryc. 11). Wisła była granicą lub przepływała w sumie przez 18 województw (w poprzednich dwu podziałach - 1946 r. i 1950 r. - było ich osiem). Rzeka rozpoczynała swój bieg w województwie bielskim i płynęła przez nie aż za Strumień, gdzie wpływała do województwa katowickiego. Od miejscowości Wola Wisła stawała się rzeką graniczą wspomnianych województw; linia graniczna dochodziła z prawego brzegu, między stawami Granicznik (!) i Oszust i biegła dalej do ujścia Przemszy (i dalej na północ). Kolejny odcinek graniczny tych samych województw zaczynał się od miejscowości Bobrek Dolny i biegł do wsi Źródła, gdzie Wisła stawała się granicą województw bielskiego i krakowskiego. Ta część granicznego biegu kończyła się

${ }^{6}$ Granica biegła zasadniczo Wisłą, z drobnym wyjątkiem. Niewielki obszar na prawym brzegu (huta szkła), naprzeciwko Sandomierza, należał do województwa kieleckiego. 
w Pasiece (obok Czernichowa). Należy zaznaczyć, że na całym opisanym do tego miejsca odcinku linia graniczna była prowadzona wzdłuż głównej linii nurtu, przy czym w niektórych miejscach biegła ona starorzeczami (ryc. 12).

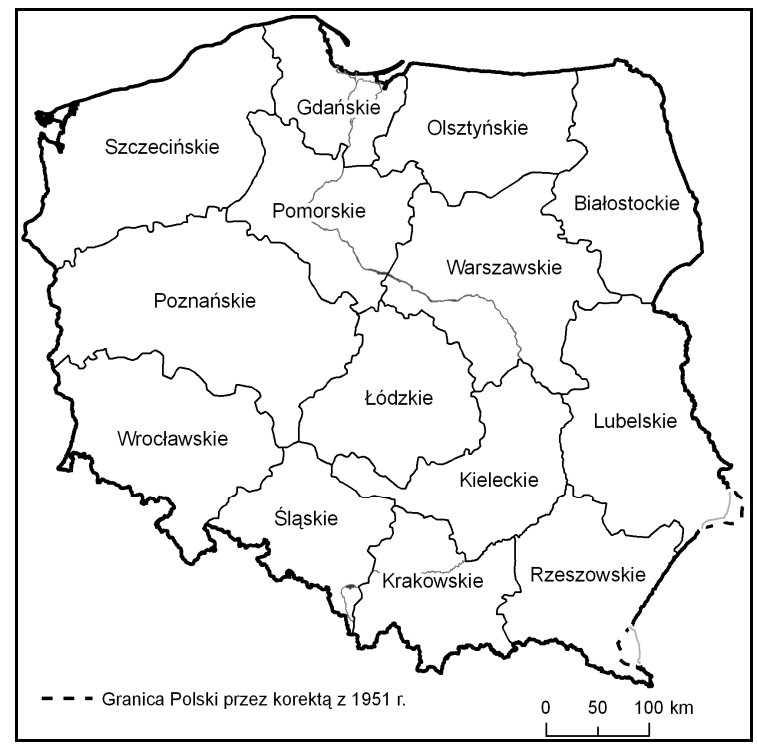

Ryc. 10. Podział administracyjny Polski na województwa od $1946 \mathrm{r}$. Źródło: opracowanie własne na podstawie: E. Olczak (2003)

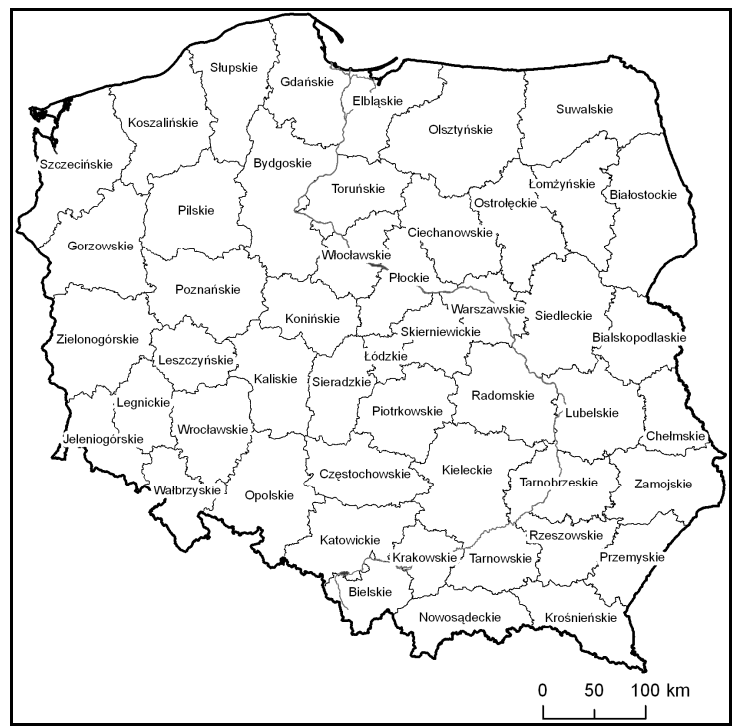

Ryc. 11. Podział administracyjny Polski na województwa od 1975 r. Źródło: opracowanie własne na podstawie: E. Olczak (2003) 


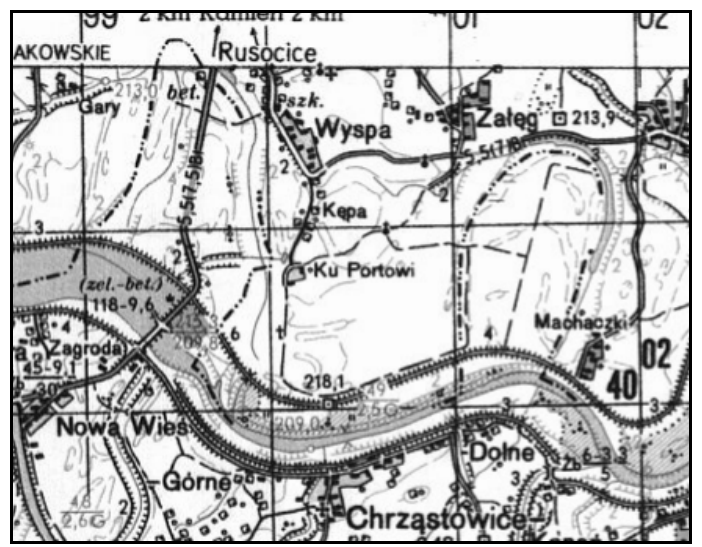

$\uparrow$ Ryc. 12. Granica województw bielskiego i krakowskiego poprowadzona starorzeczami Źródło: Mapa sztabowa M-34-76-A, skala 1:50 000 (Sztab Generalny WP, 1982)

Ryc. 13. Granica województw radomskiego i lubelskiego biegnąca martwą odnogą Wisły Źródło: Mapa sztabowa M-34-32-B, skala 1:50 000 (Sztab Generalny WP, 1982)

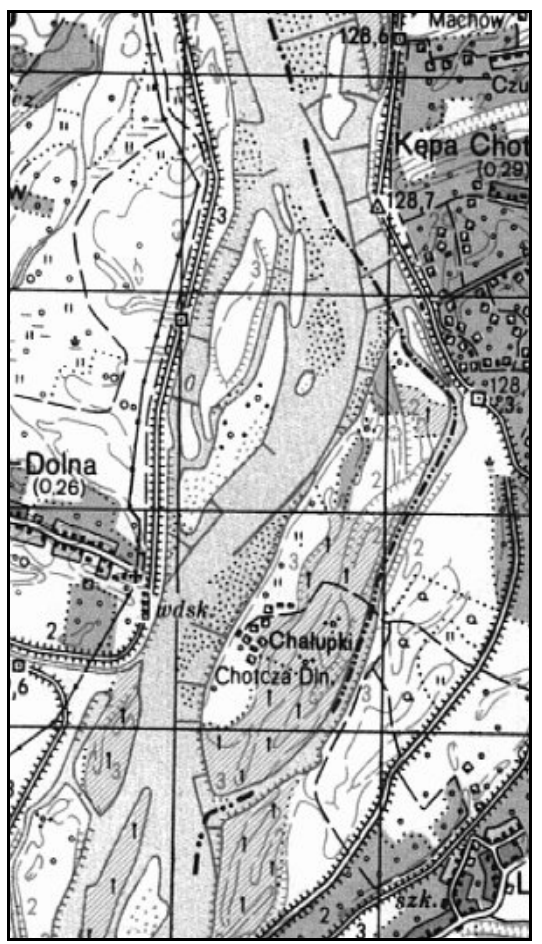

Wschodnia granica województw krakowskiego z kieleckim przecinała Wisłę na wysokości Dolan (na wschód od Nowego Brzeska) i biegła dalej rzeką do ujścia Raby. Tam rzeka stawała się granicą województw kieleckiego i tarnowskiego. Wisła przestała być granicą województwa kieleckiego we wsi Warszawa (na wschód od Szczucina), gdzie rozpoczynało się województwo tarnobrzeskie. Około $8 \mathrm{~km}$ dalej, we wsi Słupiec, w pobliżu ujścia rzeki Breń, kończyło się województwo tarnowskie a zaczynało rzeszowskie. Od ujścia rzeki Breń po ujście Wisłoki Wisła rozdzielała województwo rzeszowskie od tarnobrzeskiego. Za Popowicami (ok. $20 \mathrm{~km}$ na północ od Annopola) rzeka stawała się granicą województw tarnobrzeskiego i lubelskiego i ciągnęła się do Starych Kaliszan (na północ od Józefowa), gdzie zaczynała rozdzielać województwo radomskie od lubelskiego. Na wysokości Solca nad Wisłą granica wchodziła na ok. $5 \mathrm{~km}$ w głąb prawego brzegu; prawobrzeżne wsie Kępa Solecka i Kępa Gostecka należały do województwa radomskiego. Podobna sytuacja dotyczyła położonej pod prawym brzegiem rzeki wyspy naprzeciwko Chotczy Dolnej (ryc. 13).

W obu przypadkach granicę poprowadzono starą, zarastającą odnogą Wisły. Trudno jest ustalić przyczynę takiego przebiegu. Można przypuszczać, że kiedyś (przed pracami regulacyjnymi) to właśnie tymi ramionami płynął główny nurt rzeki. Na wysokości miejscowości Lucimia (koło Zastowa Polanowskiego) gra- 
nica wojewódzka (radomsko-lubelska) wchodziła w głąb prawego brzegu i dochodziła z powrotem do Wisły naprzeciwko miejscowości Gołąb. Następnie dalej biegła rzeką do Tyrzyna Dworskiego (naprzeciwko Kozienic), gdzie stawała się granicą województw radomskiego i siedleckiego. Poprowadzono ją do miejscowości Potycz (na południe od Góry Kalwarii), gdzie była granicą województwa siedleckiego i warszawskiego. Biegła ona rzeką do okolic wsi Kosumce, gdzie odbijała w prawo, w głąb lądu. Za Warszawą rzeka dalej płynęła przez województwo warszawskie do miejscowości Smoszewo $(9 \mathrm{~km}$ na zachód od Zakroczymia), gdzie znów stawała się rzeką graniczną województw stołecznego i płockiego. Za ujściem Bzury, przez ok. $12 \mathrm{~km}$ stanowiła granicę pomiędzy województwami płockim a skierniewickim (linia Drwały-Bieniewy). Kolejny graniczny odcinek Wisły znajdował się na Zalewie Włocławskim. Linia graniczna pomiędzy województwami płockim a włocławskim zaczynała się na lewym brzegu w Skokach Małych, następnie wychodziła na środek zbiornika i biegła nim przez ok. $8 \mathrm{~km}$ do wysokości wsi Krupa, gdzie skręcała na północ i wchodziła w głąb prawego brzegu. Dalej Wisła płynęła w całości przez województwo włocławskie, które kończyło się u południowego wierzchołka Kępy

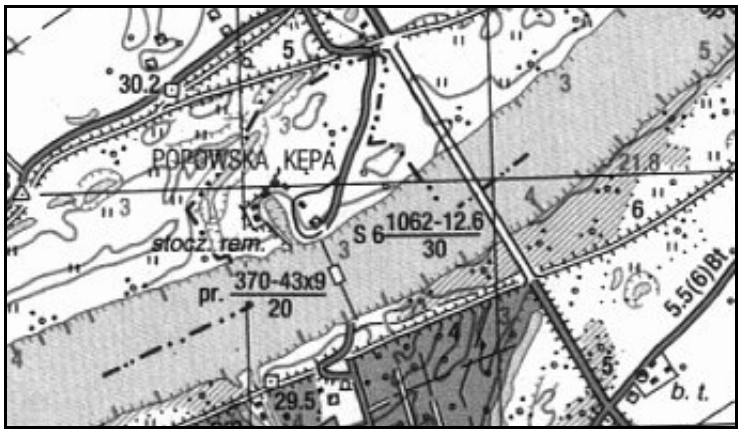

Ryc. 14. Granica województwa bydgoskiego i toruńskiego przy moście Chełmno-Świecie Źródło: Mapa sztabowa M-34-86-C, skala 1:50 000 (Sztab Generalny WP, 1982) Dzikowskiej (obok Ciechocinka). Od tego miejsca Wisła znowu stawała się linią graniczną, rozdzielającą województwo włocławskie od toruńskiego. Odcinek ten kończył się na wysokości leśniczówki Karczemka (na południe od Silna). Granica z województwem bydgoskim, poprowadzona Wisłą, zaczynała się na wysokości miejscowości Górsk i biegła środkiem nurtu za Przyłubie; od tego miejsca linia graniczna również biegła rzeką, ale lawirując między brzegami. Ten specyficzny przebieg linii granicznej ciągnął się do ujścia Górnego Kanału za Solcem Kujawskim. Dalej, do zakola Wisły pod Bydgoszczą, granica wojewódzka miała już normalny przebieg środkiem nurtu; na wysokości Plątnowa kończyło się województwo toruńskie i zaczynało bydgoskie. Na linii utworzonej pomiędzy wsiami Grabowo-Dębowiec Wisła ponownie stawała się granicą województw toruńskiego i bydgoskiego. W pobliżu mostu drogowego, łączącego Chełmno ze Świeciem, granica wchodziła nieznacznie w głąb lewego brzegu (ryc. 14). Podobna sytuacja miała 
miejsce w okolicach wsi Wielkie Stwolno; na odcinku ok. 4 km granica wchodziła, mniej więcej na $1 \mathrm{~km}$, w głąb lewego brzegu. W obu przypadkach można przypuszczać, że było to związane z dawnym kształtem koryta Wisły ${ }^{7}$.

Dalej granica $z$ województwem elbląskim biegła już środkiem nurtu. Od wsi Rusinowo (na północ od Grudziądza) Wisła była granicą między województwami bydgoskim i elbląskim. Pomiędzy Kaniczkami a Grabowem kończyło się województwo bydgoskie, a rzeka stawała się granicą między województwami elbląskim i gdańskim. Na tym ostatnim odcinku, rozciągającym się aż do ujścia Wisły do morza, granica między wspomnianymi województwami biegła środkiem nurtu.

\subsection{Wisła jako rzeka graniczna w obecnym podziale administracyjnym Polski}

Wraz ze zmianami ustrojowymi 1989 r. powrócono do tematu reformy administracji terytorialnej. Pierwszymi krokiem na tej drodze było odtworzenie samorządu lokalnego. Proces ten rozpoczął się w 1990 r.; 8 marca przywrócono samorząd gminny (Dz.U. nr 16 poz. 95, 1990), a 10 maja podjęto decyzję o wprowadzeniu samorządu terytorialnego, z gminą jako podstawową jednostką organizacyjną (Dz.U. nr 32 poz.191, 1990). W nowej sytuacji politycznej gmina stała się podstawową, niezależną od państwa wspólnotą zamieszkujących ją obywateli. Równolegle do przedstawionych powyżej zmian trwały prace i studia nad kształtem nowego podziału administracyjnego (Sobczyński, Kulesza 2006). Wyprowadzono wiele koncepcji nowego podziału. Andrzej Miszuczk w swojej publikacji pt. Regionalizacja administracyjna III Rzeczypospolitej... zidentyfikował blisko 80 takich konceptów (Miszczuk 2003). Warto wspomnieć o koncepcji A. Piskozuba przedstawionej na XVI Zjeździe Powszechnym Historyków Polskich we Wrocławiu w 1999 r. Według niej Polska powinna być podzielona na dziewięć regionów, określonych przez pomysłodawcę jako krainy historyczno-węzłowo-hydrograficzne. W kontekście niniejszej pracy koncepcja ta jest o tyle interesująca, że Wisła nie stanowiła w niej żadnej granicy administracyjnej (Piskozub 1999).

Wprowadzony w 1999 r. trójstopniowy podział administracyjny Polski na każdym z trzech poziomów: województwa, powiatu i gminy, jest częściowo oparty na Wiśle (ryc. 15). Analiza przebiegu granic administracyjnych, poprowadzonych Wisłą, została przeprowadzona na podstawie danych z Państwowego Rejestru Granic, udostępnionych w postaci warstwy w serwisie Geoportal.gov.pl.

${ }^{7}$ Kształt tej części granicy zachowany został w obecnym podziale administracyjnym na poziomie powiatu. 


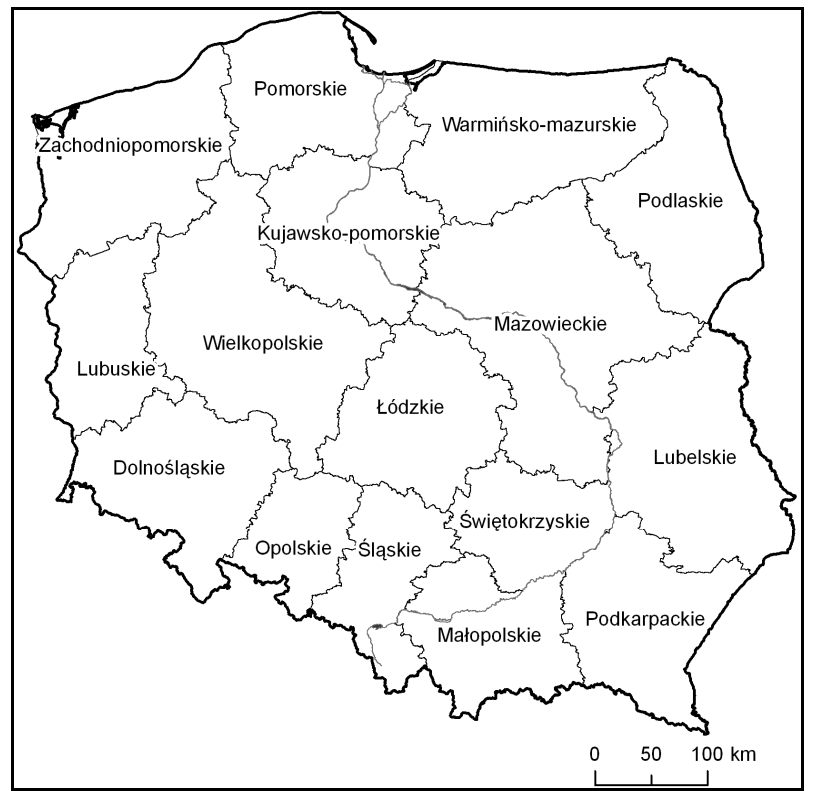

Ryc. 15. Podział administracyjny Polski na województwa z 1999 r.

Źródło: opracowanie własne na podstawie: E. Olczak (2003, s. 189)

Patrząc na bieg Wisły i poprowadzone nią granice zasadniczego podziału administracyjnego kraju (ryc. 16), można zauważyć, że odcinków, które nie byłyby granicą żadnego z trzech poziomów, jest jedynie $17 \%$. Można je powiązać zasadniczo z dużymi miastami, które są położone na obydwu brzegach rzeki (np. Kraków, Warszawa czy Toruń). Blisko 50\% całej długości rzeki zbiega się natomiast z granicami powiatowymi. Granice wojewódzkie w 23\% przebiegają po rzece, przede wszystkim w górnym i środkowym biegu Wisły. Granice najniższej jednostki podziału administracyjnego, tj. gmin, powielają zaledwie $13 \%$ całego biegu rzeki.

Wisła rozpoczyna swój bieg w województwie śląskim i płynie przez nie do Jawiszowic za Pszczyną, gdzie staje się granicą między dwoma województwami. Rozpatrując bieg Wisły tylko w województwie śląskim, granicą powiatową jest w 20\%, a gminną jedynie w 3\% biegu rzeki. Ponad 3/4 długości rzeki W województwie śląskim nie stanowi żadnej granicy podstawowego podziału administracyjnego, co może wynikać z faktu, że Wisła jest tam jeszcze niewielkim ciekiem. W Wiśle Obłaźcu (zakole Wisły) rzeka jest granicą gmin Wisła i Ustroń. Drugi taki odcinek znajduje się pomiędzy Ochabami a Drogomyślem Wisła rozdziela tu gminy Skoczów i Strumień. Od wschodniego krańca zbiornika Goczałkowickiego po Jawiszowice za Pszczyną Wisłą poprowadzono granicę powiatową - między powiatami pszczyńskim i brzeskim. 


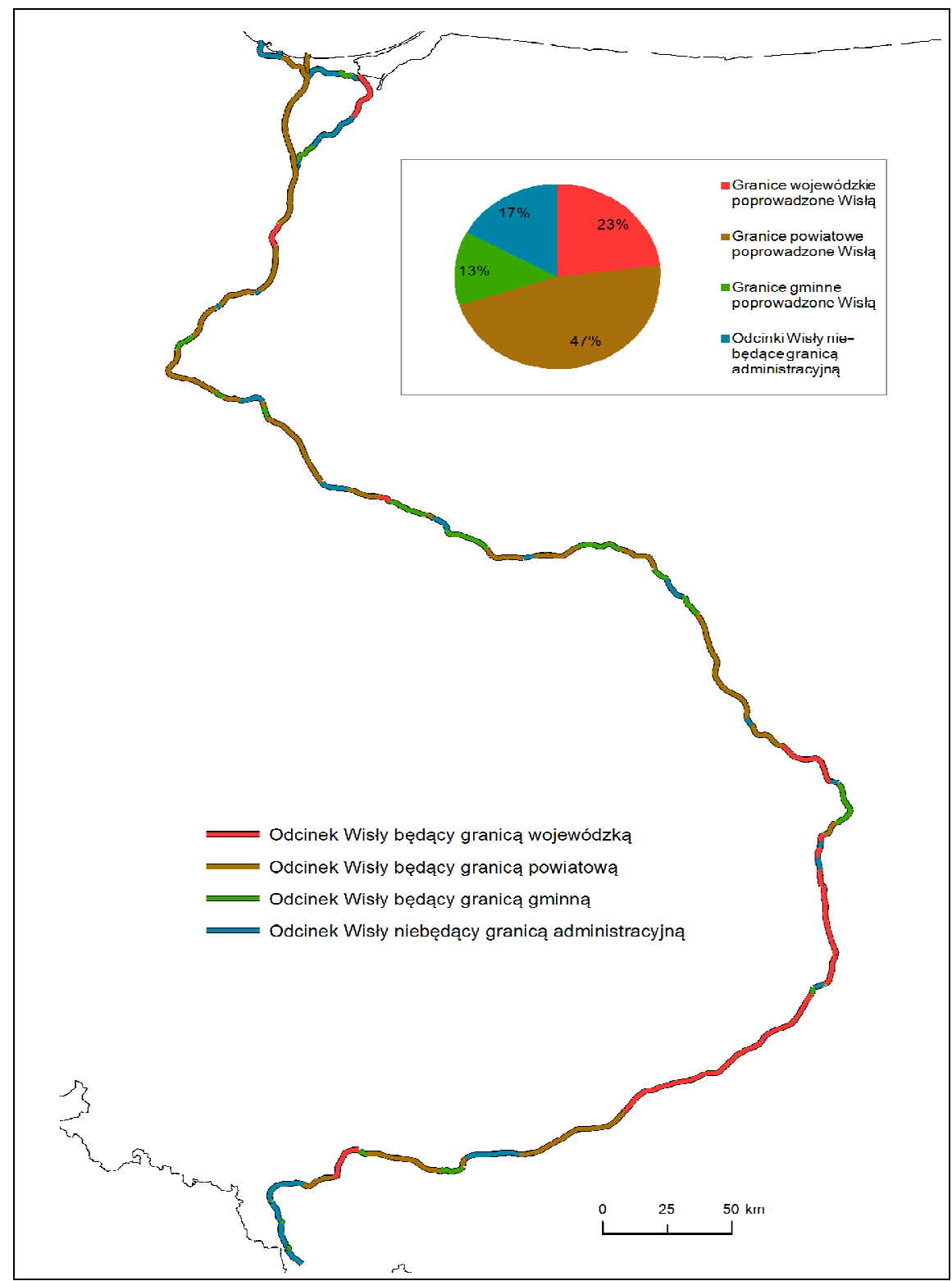

Ryc. 16. Wisła jako granica w obowiązującym podziale administracyjnym Źródło: opracowanie własne

Linia graniczna na tym odcinku nie przebiega środkiem bieżącego koryta Wisły, lecz nawiązuje do jego wcześniejszego, pełnego meandrów kształtu. Regulacja Wisły w XIX i XX w. spowodowała wyprostowanie koryta, natomiast sama granica przebiega przez starorzecza lub już zasypane meandry (ryc. 17). 


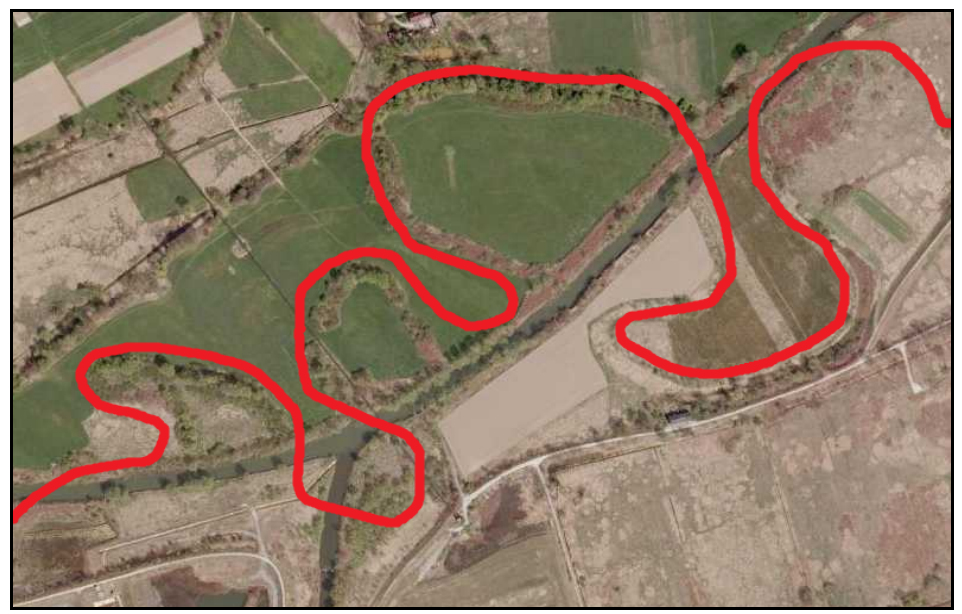

Ryc. 17. Granica powiatów pszczyńskiego i bielskiego poprowadzona dawnym korytem Wisły Źródło: Geoportal (http://geoportal.gov.pl/)

Za Jawiszowicami do samego ujścia Przemszy, na odcinku ok. 18 km, rzeka staje się granicą wojewódzką (województw śląskiego i małopolskiego). Przebieg linii granicznej, analogicznie jak w przypadku wyżej opisanej granicy powiatowej, nawiązuje do historycznego kształtu koryta Wisły.

Za ujściem Przemszy Wisła płynie przez województwo małopolskie. Granica powiatowa stanowi ok. $69 \%$ biegu rzeki w tej jednostce administracyjnej, natomiast granicą gminną jest ok. $12 \%$ biegu. Wisła jedynie w 19\% tego odcinka nie stanowi granicy administracyjnej. Za ujściem Przemszy, po zachodnie ujście kanału śluzy Dwory, Wisła jest granicą gminną - gmin Chełmek i Oświęcim (wiejskiej i miejskiej). Dalej rzeka staje się granicą powiatową - na lewym brzegu powiatu chrzanowskiego, a na prawym brzegu powiatu oświęcimskiego i wadowickiego. Podobnie jak we wcześniejszej części biegu, przebieg granicy nawiązuje do starego koryta rzeki (granica jest poprowadzona przez starorzecza i martwe meandry). Za Kłokoczynem (na wschód od przeprawy promowej Czernichów-Brzezinka) Wisła ponownie staje się granicą gminną - do Ściejowic (na północny zachód od Skawiny). Rozdziela położone na lewym brzegu gminy Czernichów i Liszki od prawobrzeżnej gminy Skawina (wiejskiej i miejskiej). Od Ściejowic po Stopień Wodny Kościuszko (wschodnie ramię starorzecza) rzeką poprowadzono granicę powiatową, oddzielającą powiat krakowski od miasta Kraków. Dalej Wisła płynie przez stolicę Małopolski do Stopnia Wodnego Przewóz (wschodnie ujście kanału śluzy Przewóz); na tym odcinku rzeka nie stanowi granicy administracyjnej. Następnie staje się ponownie granicą powiatową, rozdzielając lewobrzeżne powiaty - miasto Kraków, krakowski 
i proszowicki - od prawobrzeżnych powiatów - wielickiego, bocheńskiego, brzeskiego i tarnowskiego.

Od ujścia Nidzicy Wisła staje się granicą wojewódzką. Do wsi Nowa Wieś (na zachód od ujścia rzeki Breń) rozgranicza województwa świętokrzyskie od małopolskiego. Dalej, do Zawichostu, rzeka rozdziela województwa świętokrzyskie i podkarpackie z jednym wyjątkiem. W okolicach Sandomierza granica wojewódzka wchodzi $\mathrm{w}$ głąb prawego brzegu, włączając do lewobrzeżnego województwa świętokrzyskiego prawobrzeżne dzielnice Sandomierza. Za Zawichostem Wisła nadal jest granicą wojewódzką - do ujścia rzeki Kamiennej. Na tym odcinku oddziela województwo świętokrzyskie od lubelskiego. W dalszym biegu, po południowe okolice Zastowa Polanowskiego, Wisła stanowi granicę pomiędzy województwami mazowieckim i lubelskim. Następnie, dokładnie tak samo jak w podziale administracyjnym z 1975 r., granica ta wchodzi w głąb lewego brzegu i wraca na rzekę naprzeciwko miejscowości Gołąb, i dalej, do okolic Tyrzyna Dworskiego biegnie Wisłą.

Następny odcinek Wisły, aż do ujścia Strugi Kamienickiej (okolice wsi Krupy na wschód od Dobrzynia nad Wisłą), znajduje się w województwie mazowieckim. Podobnie jak w poprzednim województwie, rzeką poprowadzono granice administracyjne powiatu $-61 \%$ biegu Wisły w województwie mazowieckim i gminy, gdzie analogiczna wartość wynosi $24 \%$. Tylko $15 \%$ tego odcinka nie stanowi granicy administracyjnej. Za Tyrzynem Dworskim Wisła jest granicą powiatową. Na lewym brzegu są to powiaty kozienicki, grójecki i piaseczyński, natomiast na prawym brzegu powiaty garwoliński i otwocki. Za Kępą Zawadowską (na wysokości Józefowa) Wisła wpływa na terytorium miasta Warszawy, gdzie nie stanowi granicy ${ }^{8}$ na żadnym $\mathrm{z}$ trzech poziomów, zasadniczego podziału administracyjnego. Rzeka opuszcza granice miasta stołecznego za Łomiankami Dolnymi i ponownie staje się granicą powiatową rozdzielającą lewobrzeżne powiaty warszawski-zachodni i nowodworski od prawobrzeżnego powiatu legionowskiego. Na wysokości Czosnowa rzeka staje się granicą gminną i jest nią do Smoszewa. Wisła rozdziela gminy Czosnów i Leoncin (lewobrzeżne) od gmin Nowy Dwór Mazowiecki i Zakroczym (gminy miejskiej i wiejskiej). Za Smoszewem Wisła ponownie staje się granicą powiatową. Na lewym brzegu są to powiaty nowodworski i sochaczewski, a na prawym płoński i płocki. Granica powiatowa ciągnie się do Zakrzewa Kościelnego (na południowy wschód od Kępy Polskiej), gdzie Wisła powtórnie jest granicą gminną. Na lewym brzegu leżą gminy Słubice i Gąbin, a na prawym Mała Wieś, Bodzanów i Słupno. Za Jordanowem (na północ od Dobrzykowa),

${ }^{8}$ Jest za to granicą podziałów pomocniczych - rozdziela południowe i północne dzielnice: Wilanów - Wawer i Bielany - Białołęka. 
na krótkim odcinku wynoszącym ok. $3 \mathrm{~km}$, Wisła na powrót staje się granicą powiatową: miasta Płock i powiatu płockiego. W okolicy mostu Solidarności (wschodnia obwodnica Płocka) Wisła wpływa do Płocka, gdzie podobnie jak w przypadku innych dużych miast rozciętych rzeką, nie stanowi granicy administracyjnej. Za stocznią rzeczną Wisła opuszcza Płock i ponownie, na krótkim odcinku (ok. $3 \mathrm{~km})$ - do Popłacina - staje się granicą miasta Płock i powiatu płockiego. Pozostały odcinek biegu Wisły w województwie mazowieckim związany jest z granicą gminną, rozciągającą się od Popłacina po Skoki Małe (nad Zalewem Włocławskim), gdzie rzeka rozdziela gminy: Nowy Duninów (na lewym brzegu) oraz Stara Biała i Brudzeń Duży (na prawym brzegu).

Od wsi Skoki Małe po wieś Krupa Wisłą poprowadzono granicę wojewódzką. Na krótkim, bo wynoszącym zaledwie ok. 3 km, odcinku rzeka rozgranicza województwo mazowieckie i kujawsko-pomorskie.

Bieg Wisły w województwie kujawsko-pomorskim jest także związany z granicami zasadniczego podziału administracyjnego kraju. Wisła w 79\% swojej długości w tym województwie stanowi granicę powiatową, natomiast granice gminne opierają się zaledwie na 9\% długości rzeki. Pozostałe 12\% nie stanowi granicy administracyjnej. Do granic miasta Włocławek Wisłą biegnie granica powiatowa, rozdzielająca powiat włocławski (na lewym brzegu) i powiat lipnowski (na prawym brzegu). Za Zarzeczewem rzeka płynie w obrębie miasta i nie stanowi granicy administracyjnej aż do wysokości dzielnicy Zazamcze, gdzie znów staje się granicą powiatową biegnącą po okolice Silna. Na lewym brzegu leżą powiaty: miasto Włocławek, włocławski i aleksandrowski, a na prawym lipnowski i toruński. Za Silnem Wisła ponownie staje się granicą gminą lewobrzeżnej gminy Wielka Nieszawka i dwóch prawobrzeżnych gmin Obrowo i Lubicz. Następnie, na krótkim odcinku Silno - ujście Drwęcy, rzeka znowu staje się granicą powiatową - miasta Toruń (na lewym brzegu) i powiatu toruńskiego (na prawym). Od ujścia Drwęcy do Małej Nieszawki Wisła płynie przez Toruń, gdzie nie stanowi granicy administracyjnej. Dalej za Toruniem rzeka na powrót staje się granicą powiatową (miasta Toruń i powiatu toruńskiego) rozciągającą się jedynie na krótkim odcinku - do Starego Torunia za dawnym portem drzewnym. Od tego miejsca Wisła z powrotem staje się granicą gminną - gminy Wielka Nieszawka (lewy brzeg) i Zławieś Wielka (prawy brzeg). Na wysokości Górska Wisła zmienia się w granicą powiatową. Oddziela lewobrzeżne powiaty bydgoski i miasto Bydgoszcz od prawobrzeżnego powiatu toruńskiego. Za Strzelcami Dolnymi (na północ od Bydgoszczy) Wisła jest granicą gminy Dobrcz (lewy brzeg) i Dąbrowa Chełmińska (prawy brzeg). Za wsią Kozielec rzeka ponownie staje się granicą powiatową i jest nią, z jednym wyjątkiem, aż do granicy z województwem pomorskim. Na lewym brzegu jest to 
powiat świecki, a na prawym powiaty: chełmiński ${ }^{9}$, grudziądzki, miasto Grudziądz i znów grudziądzki.

Za wsią Mały Wełcz Wisła jest granicą wojewódzką pomiędzy województwami kujawsko-pomorskim i pomorskim. Odcinek graniczny kończy się w okolicach wsi Grabowo (na północny wschód od Nowego). Przebieg tej granicy jest niemalże taki sam jak w poprzednim podziale administracyjnym kraju z $1975 \mathrm{r}$.

Zbieżność biegu Wisły z przebiegiem granic zasadniczego podziału administracyjnego $\mathrm{w}$ województwie pomorskim jest bardziej skomplikowana niż w przypadku opisanych wcześniej województw. Wynika to z faktu, że rzeka rozdziela się na ramiona ujściowe, $\mathrm{z}$ których część stanowi granicę administracyjną. Uogólniając, $60 \%$ biegu Wisły w województwie pomorskim stanowi granicę powiatową (biegnąca zarówno Leniwką, Nogatem, jak i Martwą Wisłą), $17 \%$ biegu jest granicami gminnymi (jedynie Nogat i Szkarpawa), a 23\% biegu nie stanowi granicy administracyjnej (Nogat, Martwa Wisła i Szkarpawa). Od Grabowa po ujście do Bałtyku Wisła jest tylko granicą powiatową. Na lewym brzegu są to powiaty: tczewski, gdański i miasto Gdańsk, na prawym natomiast: kwidzyński, sztumski, malborski i nowodworski. Szczególnie interesujący przebieg ma fragment granicy między powiatami tczewskim a malborskim w okolicy mostów w Tczewie. Jest to jedyne miejsce wzdłuż całej długości Wisły, gdzie kształt granicy został dokładnie dopasowany do obiektu mostowego (ryc. 18).

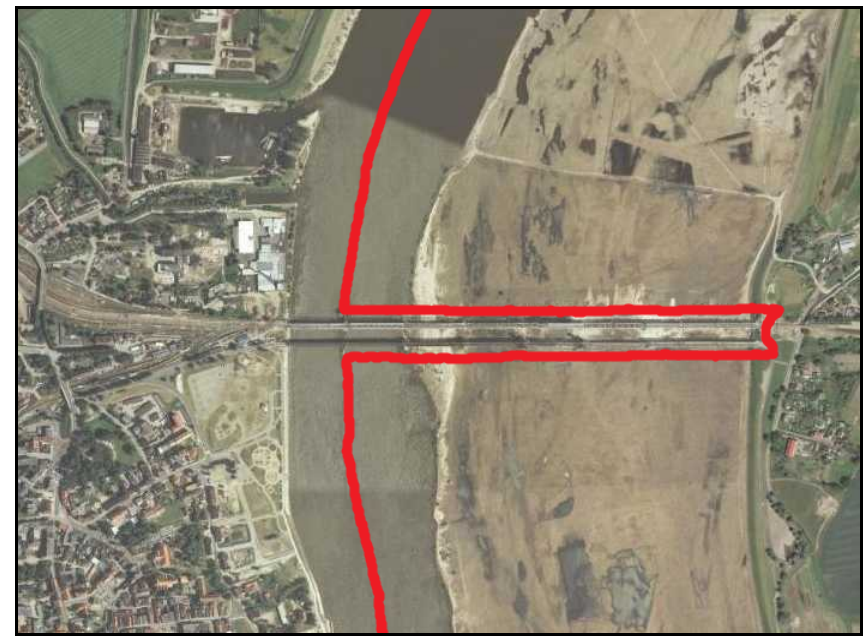

Ryc. 18. Granica powiatu tczewskiego i malborskiego w Tczewie Źródło: Geoportal (http://geoportal.gov.pl/)

${ }^{9}$ To tu znajduje się wspomniany wyjątek - granica na odcinku ok. 1,5 km wchodzi w głąb lewego brzegu. 
Bieg Nogatu i poprowadzone nim granice wiążą się z każdym z trzech poziomów zasadniczego podziału administracyjnego. Przez kanał śluzy w Białej Górze przebiega granica powiatów kwidzyńskiego i sztumskiego. Dalej, do ujścia starego kanału prowadzącego do Piekła, Nogat nie jest granicą administracyjną. Następnie, niemalże po śluzę Szonowo, poprowadzono Nogatem granicę powiatową - powiatów sztumskiego i malborskiego. Następnie, aż po tereny w strefie śluzy Michałowo, Nogatem biegnie granica gminna z dwoma niewielkimi wyjątkami, gdzie Wisła nie jest granicą administracyjną. Są to okolice śluzy Szonowo i fragment biegu w Malborku. Nogat rozdziela położone na lewym brzegu gminy Malbork (miejska i wiejska) i Nowy Staw od prawobrzeżnych gmin Malbork (gmina miejska) i Stare Pole. Za śluzą Michałowo Nogat staje się granicą wojewódzką, z województwem warmińsko-mazurskim, do ujścia do Zalewu Wiślanego.

Większość biegu Szkarpawy nie jest związana z granicami administracyjnymi. Jedynie od wsi Chełmek (na wschód od Rybiny) rzeka staje się granicą gminną do ujścia do Zalewu Wiślanego. Szkarpawa rozdziela leżącą na lewym brzegu (północnym) gminę Sztutowo od położonych na prawym brzegu (południowym) gmin Stegna i Nowy Dwór Gdański (gmina wiejska).

Część Martwej Wisły (do Górek Wschodnich) jest granicą powiatową. Martwa Wisła oddziela leżący na lewym brzegu (południowym) powiat gdański od położonego na prawym brzegu (północnym) miasta Gdańsk. Pozostała część Martwej Wisły, wraz z Wisłą Śmiałą, nie stanowi granicy administracyjnej.

\section{Podsumowanie}

Podsumowując przedstawiony powyżej opis znaczenia Wisły w obowiązującym podziale administracyjnym kraju, można zauważyć, że na wielu odcinkach rzeki przebieg granicy ${ }^{10}$ od wielu lat, a nawet stuleci, pozostaje niezmienny (ryc. 19). Pierwszy taki odcinek (ciemnozielony) znajduje się pomiędzy Jawiszowicami a Oświęcimiem (ujściem Przemszy). Jest to fragment granicy, która ukształtowała się już pod koniec XV w. (od ujścia Białej do ujścia Przemszy) pomiędzy Królestwem Polskim a Królestwem Czeskim. Stabilność granicy na tym odcinku Wisły jest wyjątkowo duża, gdyż trwa już (w różnych formach) ponad pięćset lat. Kolejny godny uwagi odcinek (żólty) rozciąga się od Zawichostu po Zastów Polanowski. Jest to ukształtowana za czasów Jagiellonów granica wojewódzka pomiędzy województwami lubelskim i sandomierskim (Zawichost - Dęblin), która również funkcjonuje ponad pięćset lat. Historycz-

${ }^{10}$ Odniesiono się jedynie do granic wojewódzkich. 
nego uzasadnienia faktu, że Wisła jest obecnie granicą województw małopolskiego, świętokrzyskiego i podkarpackiego (jasnozielony), należy się doszukiwać dopiero w odróżnieniu od opisanych powyżej dwóch odcinków, w okresie po pierwszym rozbiorze. Wtedy to Wisłą Małopolską została poprowadzona granica pomiędzy I Rzeczpospolitą a Austrią. Stabilność tej granicy można uznać też za znaczną, bo trwa już, z niewielkimi przerwami, ponad dwa stulecia. Ostatnim odcinkiem granicznym (czerwony), cechującym się największą, w skali całej Wisły jako rzeki granicznej, stabilnością jest granica pomiędzy województwami kujawsko-pomorskim a pomorskim (Mały Wełcz - Grabowo). Uogólniając, można przyjąć, że jest to fragment granicy, która rozdzielała państwo pierwszych Piastów od plemion pruskich. Innymi słowy - idea granicy na tym odcinku trwa już ponad tysiąc lat.

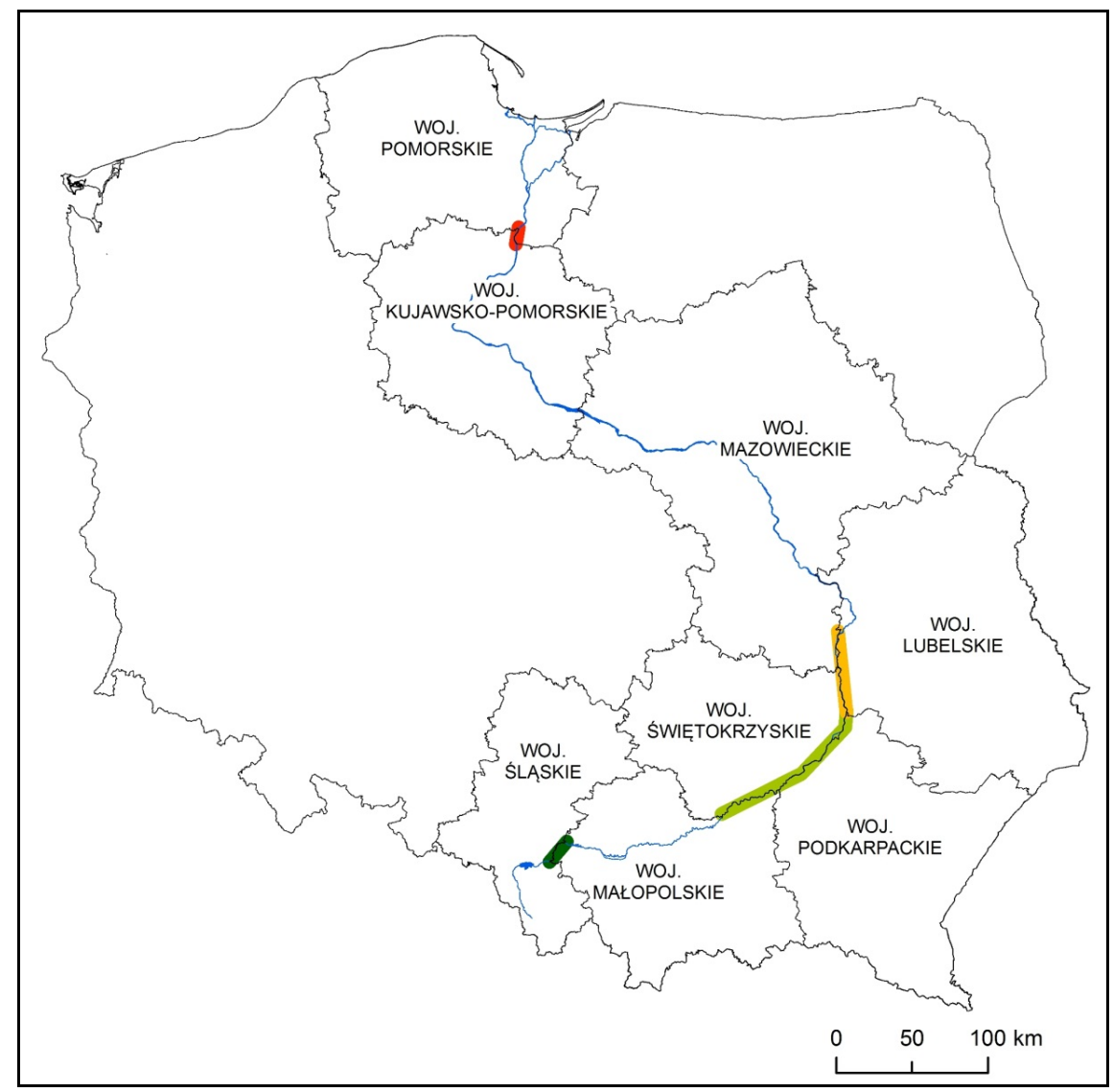

Ryc. 19. Odcinki Wisły jako granicy o największej stabilności (objaśnienia w tekście)

Źródło: opracowanie własne 
Warto podkreślić, że jedynie $17 \%$ biegu Wisły nie stanowi granicy z żadnego $\mathrm{z}$ trzech poziomów zasadniczego podziału administracyjnego Polski. Są to głównie te odcinki rzeki, które wiążą się z Krakowem, Warszawą, Toruniem, czyli dużymi miastami położonymi na obydwu brzegach Wisły. Pozostałe $83 \%$ biegu rzeki stanowią granice: wojewódzkie (23\%), powiatowe $(47 \%)$ i gminne $(13 \%)$.

\section{Literatura}

Babirecki J., 1895, Polska w roku 1771, Kraków.

Gloger Z., 1991, Geografia historyczna ziem dawnej Polski, reprint, Warszawa.

Janiszewski M., 1959, Regiony geograficzne Polski, Warszawa.

Kałuski S., 1992, Rzeki graniczne a kształtowanie się więzi regionalnych $w$ Europie, Warszawa.

Kałuski S., 1997, Granice polityczne, naturalne i sztuczne - anachronizm czy aktualny problem?, Warszawa.

Koter M., Kulesza M., 2001, Geographical and historical grounds of formation of borders of former and present-day Poland, [w:] Koter M., Heffner K. (red.), Changing role of border areas and regional policies, Region and Regionalism, No. 5, ŁódźOpole.

Manteuffel T., 1929, Metoda oznaczania granic w geografii historycznej, [w:] Bachulski H. (red.), Ksiegga pamiątkowa ku uczczeniu 25-letniej działalności naukowej prof. Marcelego Handelsmana, Warszawa.

Manteuffel T., Dowiat J., 1979, Monarchia wczesnopiastowska, [w:] Tazbir J. (red.), Zarys historii Polski, Warszawa.

Mielcarek A., 2008, Podziaty terytorialno-administracyjne II Rzeczypospolitej $w$ zakresie administracji zespolonej, Warszawa.

Miszczuk A., 2003, Regionalizacja administracyjna III Rzeczypospolitej. Koncepcje teoretyczne a rzeczywistość, Lublin

Olczak E. (red.), 2003, Atlas historii Polski. Mapy i komentarze, Warszawa.

Olczak E., Sienkiewicz W. (red.), 2006, Ilustrowany atlas historii Polski, t. 1: Od źródeł po schyłek Jagiellonów, Warszawa.

Piskozub A., 1987, Dziedzictwo polskiej przestrzeni. Geograficzno-historyczne podstawy struktur przestrzennych ziem polskich, Wrocław.

Piskozub A., 1995, Polska w cywilizacji zachodniej, Gdańsk.

Piskozub A., 1999, Dziedzictwo tradycji historycznej jako podstawa wspótczesnej tożsamości regionalnej ziem polskich, referat na XVI Zjazd Powszechny Historyków Polskich, Wrocław.

Podwińska Z., 1978, Stosunki społeczne i polityczne, [w:] Dembińska M., Podwińska Z. (red.), Historia kultury materialnej Polski w zarysie, t. 1: Od VII do XII wieku, Wrocław. 
Rajman J., Zioło Z., 1992, Przemiany sieci miast regionu górnej Wisty w XIX i XX wieku, [w:] Rajman J., Hempel J. (red.), Wisła w dziejach i kulturze Polski. Studia nad gospodarka i siecia osadniczą regionu górnej Wisty, Warszawa.

Skrzyp J., 2007, Geografia administracyjna i polityczna, Siedlce.

Sobczyński M., 1984, Niezmienność dawnych granic politycznych na obszarze Polski, Łódź.

Sobczyński M., 1994, The influence of past political divisions of the territory of Poland upon the regional structure of the country, [w:] Koter M. (red.), Inner divisions, Region and Regionalism, No. 1, Łódź-Opole, s. 103-116.

Sobczyński M., 2008, Historia geografii politycznej, [w:] Jackowski A., Liszewski S., Richling A. (red.), Historia geografii polskiej, Warszawa.

Sobczyński M. Kulesza M., 2006, Miejsce i rola powiatu w tradycji podziału terytorialnego Polski, Łódź.

Stoksik J., 1990, Wisła pod Krakowem przedmiotem polsko-austriackiego konfliktu granicznego $w$ latach 1780-1782, [w:] Kiryk F. (red.), Wista $w$ dziejach i kulturze Polski. Studia i materiały z dziejów osadnictwa i gospodarki górnej Wisty w okresie przedrozbiorowym, Warszawa.

Śliwiński B., 1989, Problem granicznego charakteru Wisty w dziejach Kujaw i Mazowsza do końca XII w. na tle stosunków własnościowo-osadniczych, [w:] Gierszewski S. (red.), Wisła $w$ dziejach i kulturze Polski. Osadnictwo nad Dolna Wisła w średniowieczu, Warszawa.

Tazbir J. (red.), 1979, Zarys historii Polski, Warszawa.

\section{Mapy i dokumenty}

Das deutsche Interessengebiet, 1939/1940, Mapa obszaru interesów niemieckich, Reichsamt für Landesaufnahme.

Mapa sztabowa M-34-76-A w skali 1:50 000, 1982, Sztab Generalny WP.

Ustawa z dnia 8 marca 1990 r. o samorządzie gminnym, 1990, Dz.U. nr 16 poz. 95.

Ustawa z dnia 10 maja 1990 r. Przepisy wprowadzające ustawę o samorządzie terytorialnym i ustawę o pracownikach samorządowych, 1990, Dz.U. nr 32 poz.191.

Wojskowa mapa topograficzna w skali 1:50 000, 1982,WZkart, Sztab Generalny WP.

\section{Strony internetowe}

Geoportal: http://geoportal.gov.pl/ (dostęp 26.05.2012).

The role of the Vistula River as a border on the background of historical divisions of Poland and its importance in the current administrative division

\section{Summary}

This work concerns the importance of the Vistula as a border borrowed from nature in historical and current divisions of Poland. Forms of this division have changed over the centuries several times. The first form of spatial government was the so-called 
neighboring communities - opola. In the Middle Ages there were new forms of organization of space such as a province and castellany. In the following centuries these forms changed and evolved. There were counties, municipalities and provinces. The period of the partitions of Poland, as well as two world wars brought changes to the internal division of the country, imposed by the invader administration. Political boundaries were repeatedly changed too. In many of these divisions, the Vistula River served as a natural basis for the designation of a border. It should be noted, that there are places where the border is more than five hundred years old. The current administrative landscape of Poland is a result of government reforms in 1999, which established a three-tier division of the country. The role of the Vistula as a border in this division is also clearly visible.

Key words: borders on the rivers, the Vistula, administrative divisions.

Łukasz Twardowski, dr

Katedra Geografii Politycznej i Studiów Regionalnych, Wydział Nauk Geograficznych, Uniwersytet Łódzki, 90-142 Łódź, ul. Kopcińskiego 31 